\title{
PENGARUH PENILAIAN PRESTASI KERJA KARYAWAN TETAP TERHADAP PROMOSI JABATAN PADA PT. BANK BUKOPIN,Tbk. CABANG PALEMBANG
}

\author{
Riri Hanifa \\ Anton Trianto \\ Mahdi Hendrich \\ Dosen Tetap Fakultas Ekonomi Universitas Sjakhyakirti Palembang
}

\begin{abstract}
ABSTRAK
Penelitian ini bertujuan untuk mengetahui : (1) sistem penilaian prestasi kerja karyawan pada PT. Bank Bukopin,Tbk Cabang Palembang, (2) sistem promosi jabatan pada PT. Bank Bukopin,Tbk Cabang Palembang, (3) variabel penilaian prestasi kerja berpengaruh signifikan terhadap promosi jabatan pada PT. Bank Bukopin,Tbk Cabang Palembang. Sampel yang digunakan dalam penelitian ini adalah karyawan tetap PT. Bank Bukopin,Tbk Cabang Palembang sebanyak 30 responden, data diperoleh melalui kuesioner dan analisis dokumen. Adapun teknik sampling yang dipergunakan adalah teknik nonprobability sampling dengan metode sampling purposive. Metode analisis yang digunakan adalah kuantitatif dengan pendekatan asosiatif dengan menggunakan program SPSS for windows versi 23.0. Hasil penelitian menunjukkan bahwa koefisien determinasi $\mathrm{R}^{2}$ sebesar 0,720 yang berarti penilaian prestasi kerja berpengaruh secara signifikan terhadap promosi jabatan sebesar $72 \%$, nilai yang tersisa sebesar $28 \%$ dipengaruhi oleh variabel lain yang tidak termasuk dalam penelitian ini, yaitu ada tidaknya lowongan atau informasi jabatan yang dituju/level lebih tinggi dan tidak memiliki catatan negatif.
\end{abstract}

Kata kunci: penilaian prestasi kerja, promosi jabatan

\section{ABSTRACT}

This study aims to determine: (1) employee performance appraisal system at PT. Bank Bukopin, Tbk Palembang Branch, (2) the job promotion system at PT. Bank Bukopin, Tbk Palembang Branch, (3) the variable performance appraisal has a significant effect on the job promotion of PT. Bank Bukopin, Tbk Palembang Branch. The sample used in this study is permanent employees of PT. Bank Bukopin, Tbk Palembang Branch are 30 respondents, data obtained through questionnaires and document analysis. The sampling technique used is nonprobability sampling technique with purposive sampling method. The analytical method used is quantitative with associative approach using SPSS for Windows version 23.0. The results showed that the coefficient of determination $R^{2}$ was 0.720 , which means that the performance appraisal had a significant effect on job promotion by $72 \%$, the remaining value of $28 \%$ was influenced by other variables not included in this study, namely the absence of vacancies or information of the intended position / higher level and do not have negative record.

Keywords: performance appraisal, job promotion. 


\section{Latar Belakang}

Dalam menghadapi arus globalisasi, sumber daya manusia (SDM) memegang peranan yang sangat dominan dalam aktivitas atau kegiatan perusahaan. Berhasil atau tidaknya perusahaan dalam mencapai tujuan yang ditetapkan sebelumnya sangat tergantung pada kemampuan sumber daya manusianya (karyawan) dalam menjalankan tugas-tugas yang diberikan kepadanya. Setiap organisasi pemerintah maupun swasta dituntut bekerja lebih cepat, efektif dan efesien. Faktor sumber daya manusia perlu mendapat prioritas utama dalam pengelolaannya agar pemanfaatan sesuai dengan yang diharapkan oleh organisasi atau perusahaan tersebut dalam usaha mencapai tujuan yang telah ditetapkan. Oleh karena itu, setiap perusahaan perlu memikirkan bagaimana cara yang dapat dilakukan untuk mengembangkan sumber daya manusianya agar dapat mendorong kemajuan bagi perusahaan dan bagaimana caranya agar karyawan tersebut memiliki produktivitas yang tinggi, yang tentunya pimpinan perusahaan perlu memotivasi karyawannya (Tajudin, 2012).

Dasar pengembangan SDM perusahaan dapat dilakukan dengan menilai prestasi kerja karyawannya. Melalui penilaisran prestasi kerja akan diketahui seberapa baik karyawan telah melaksanakan tugas-tugas yang diberikan kepadanya, sehingga perusahaan dapat menetapkan balas jasa yang sepantasnya atas prestasi kerja tersebut. Dari hasil tersebut, perusahaan dapat mengembangkan suatu perencanaan SDM berupa jalur karir atau promosi jabatan para karyawan.

Penilaian prestasi kerja adalah proses dimana organisasi mengevaluasi atau menilai prestasi kerja karyawan. Penilaian prestasi kerja berupaya untuk menjaga kinerja, memperbaiki, dan mendorong karyawan agar dapat bekerja lebih baik lagi. Dengan mengadakan penilaian prestasi kerja tersebut, pihak manajemen dapat mengetahui sampai sejauh mana sikap dan perilaku kerja karyawan, keberhasilan pelaksanaan tugas karyawan (prestasi kerja) dan potensi pengembangan yang telah dilakukan. Namun dalam pelaksanaan penilaian prestasi kerja tidaklah semudah yang direncanakan. Penilaian prestasi kerja yang baik harus berdasarkan objektivitas dan keadilan, sehingga hasilnya dapat digunakan sebagai dasar pengambilan keputusan dalam menentukan promosi jabatan karyawan (Syamsir, 2017).

Pengembangan SDM dapat dilakukan dengan berbagai cara, salah satunya adalah dengan melalui promosi jabatan. Dengan adanya target promosi jabatan, pegawai akan merasa dihargai, diperhatikan, dibutuhkan dan diakui kemampuan kerjanya oleh atasan sehingga mereka akan menghasilkan keluaran (output) yang tinggi. Promosi jabatan dilaksanakan untuk mengoptimalkan sumber daya manusia yang dimiliki organisasi, selain itu promosi jabatan bertujuan untuk meregenerasi sumber daya manusia dalam organisasi demi kelangsungan organisasi tersebut (Hanum et all, 2015).

Adapun pengertian promosi jabatan menurut Siagian (2009:169) adalah pemindahan pegawai atau karyawan dari satu jabatan atau tempat kepada jabatan atau tempat lain yang lebih tinggi serta diikuti oleh tugas, tanggung jawab dan wewenang yang lebih tinggi dari jabatan yang diduduki sebelumnya. Menurut Hasibuan (2002:108) promosi jabatan adalah perpindahan yang memperbesar wewenang dan tanggung jawab ke jabatan yang lebih tinggi di dalam suatu organisasi yang diikuti dengan kewajiban, hak, status dan penghasilan yang lebih besar.

Menurut Werther dan Davis (1996:261) : "A promotion occurs when an employee is moved from one job to another job that is higher in pay, responsibility, organization level." (Promosi terjadi ketika seorang karyawan dipindahkan dari satu jabatan ke jabatan lain yang lebih tinggi imbalan, tanggung jawab dan tingkatannya dalam organisasi).

PT. Bank Bukopin,Tbk merupakan subyek dalam penelitian ini. Sejak berdiri pada tahun 1970, Bank Bukopin memfokuskan diri pada segmen UMKMK (Usaha Menengah Kecil, Mikro dan Koperasi), saat ini telah tumbuh dan berkembang menjadi bank yang masuk ke kelompok bank menengah di Indonesia dari sisi aset. Seiring dengan terbukanya 
kesempatan dan peningkatan kemampuan melayani kebutuhan masyarakat yang lebih luas, Bank Bukopin telah mengembangkan usahanya ke segmen komersial dan konsumer. (www.bukopin.co.id)

Karyawan merupakan aset utama bagi PT. Bank Bukopin,Tbk dimulai dengan merekrut bakat-bakat terbaik di bidangnya lalu menyediakan sarana dan sumber daya yang diperlukan, termasuk pelatihan-pelatihan komprehensif yang berkelanjutan, sehingga karyawan dapat terus mengembangkan kompetensi dan menghasilkan kinerja terbaik di bidangnya masing-masing.

Pihak-pihak yang berkepentingan terhadap promosi jabatan adalah karyawan, manajer dan perusahaan. Bagi manajer, promosi jabatan yang diberikan kepada karyawan sebagai reward atas kinerja yang dilakukan oleh karyawan dalam melaksanakan tanggung jawabnya. Bagi perusahaan, promosi jabatan bertujuan untuk meregenerasi sumber daya manusia yang dimiliki demi kelangsungan perusahaan tersebut. Penilaian prestasi kerja terhadap pegawai merupakan tolak ukur utama dalam pengembangan SDM.

Fenomena yang sering terjadi adalah, kebijakan promosi jabatan tidak hanya dipengaruhi oleh hasil kinerja tetapi didasarkan pada selera pimpinan. Promosi jabatan bukan lagi karena prestasi dan pengabdian, tetapi karena kedekatan dan balas budi. Siapa yang dekat dengan pimpinan akan dipilih, meskipun ada karyawan lain yang memenuhi kriteria untuk dipromosikan (Syamsir, 2017).

Masalah yang dibahas pada penelitian ini hanya terbatas proses penilaian prestasi kerja karyawan yang berpengaruh terhadap keputusan perusahaan untuk mempromosikan seorang karyawan pada PT. Bank Bukopin,Tbk Cabang Palembang. Peneliti membatasi penelitian ini hanya pada karyawan tetap Bank Bukopin Cabang Palembang, unit kerja Bisnis dan Operasional, tidak termasuk karyawan outsourcing.

\section{Kajian Pustaka}

\section{Manajemen Sumber Daya Manusia}

Manajemen sumber daya manusia, disingkat MSDM, adalah suatu ilmu atau cara bagaimana mengatur hubungan dan peranan sumber daya (tenaga kerja) yang dimiliki oleh individu secara efisien dan efektif serta dapat digunakan secara maksimal sehingga tercapai tujuan (goal) bersama perusahaan, karyawan dan masyarakat menjadi maksimal. MSDM didasari pada suatu konsep bahwa setiap karyawan adalah manusia bukan mesin, dan bukan semata menjadi sumber daya bisnis. Manajemen sumber daya manusia juga menyangkut desain dan implementasi sistem perencanaan, penyusunan karyawan, pengembangan karyawan, pengelolaan karier, evaluasi kinerja, kompensasi karyawan dan hubungan ketenagakerjaan yang baik. Manajemen sumber daya manusia melibatkan semua keputusan dan praktik manajemen yang mempengaruhi secara langsung sumber daya manusianya. (www.wikipedia.com).

Manajemen sumber daya manusia (MSDM) mencakup perencanaan untuk mencegah penggunaan tenaga kerja secara berlebihan atau dibawah kebutuhan pendayagunaan, guna mencapai hasil kerja yang optimal dan menjamin cadangan tenaga kerja yang cukup terampil. Dalam suatu organisasi atau perusahaan peranan manajemen sumber daya manusia (SDM) sangatlah penting. Hal ini dapat kita mengerti, karena tanpa SDM, suatu organisasi tidak mungkin berjalan. Manusia merupakan penggerak dan pengolah faktor-faktor produksi lainnya seperti modal, bahan mentah, peralatan dan lain-lain (Andriani, 2018).

Menurut Bangun (2012:6) mengatakan bahwa Manajemen Sumber Daya Manusia dapat didefinisikan sebagai suatu proses perencanaan, pengorganisasian, penyusunan staf, penggerakan dan pengawasan terhadap pengadaan, pengembangan, pemberian kompensasi, pengintegrasian, pemeliharaan dan pemisahan tenaga kerja untuk mencapai tujuan organisasi. Sedangkan menurut Suwatno dan Tjutju Yuniarsih (2016:3) menjelaskan bahwa Manajemen Sumber Daya Manusia adalah serangkaian kegiatan pengelolaan sumber daya manusia yang 
memusatkan kepada praktek dan kebijakan, serta fungsi-fungsi manajemen untuk mencapai tujuan organisasi. Dalam proses pencapaian tujuan ini, maka manajemen sumber daya manusia mempelajari bagaimana memperoleh, mengembangkan, mengevaluasi dan mempertahankan tenaga kerja yang baik dalam jumlah dan tipe yang tepat. Manajemen personalia dapat berhasil bila mampu menyediakan tenaga kerja yang berkompeten untuk melaksanakan pekerjaan yang harus dilakukan.

\section{Pengertian Prestasi Kerja}

Ada beberapa pendapat mengenai definisi prestasi kerja. Menurut Mangkunegara (2002:67), prestasi kerja adalah "Hasil kerja secara kualitas dan kuantitas yang dicapai oleh seorang karyawan dalam melaksanakan tugasnya sesuai dengan tanggung jawab yang diberikan kepadanya."

Menurut Hasibuan (2003:105), prestasi kerja adalah suatu hasil kerja yang dicapai seseorang dalam melakukan tugas-tugas yang dibebankan kepadanya yang didasarkan pada kecakapan, pengalaman, dan kesungguhan serta ketepatan waktu. Prestasi kerja dipengaruhi oleh tiga faktor yakni kemampuan dan minat seorang pekerja, kemampuan dan penerimaan atas penjelasan delegasi tugas dan peran, serta tingkat motivasi seorang pekerja.

Mangkuprawira (2004), mendefinisikan penilaian prestasi kerja sebagai proses yang dilakukan perusahaan dalam mengevaluasi kinerja pekerjaan seseorang. Dari hasil pembahasan di atas, maka pelaksanaan penilaian prestasi kerja di dalam suatu organisasi sangatlah penting. Dengan penilaian prestasi pihak perusahaan dapat mengambil tindakan yang dapat dilakukan untuk meningkatkan keterampilan dan mengembangkan karyawannya, sesuai dengan potensi dan keterampilan dari karyawan tersebut.

\section{Penilaian Prestasi Kerja}

Penilaian prestasi kerja adalah sebagai penyedia informasi yang sangat membantu dalam membuat dan menerapkan keputusan-keputusan seperti promosi jabatan, peningkatan gaji, pemutusan hubungan kerja dan transfer (Flippo, 1996:84). Sedangkan pengertian penilaian prestasi kerja menurut Lloyd L. Byars dan Leslie W. Rue (2004:251) adalah Performance appraisal is a process of determining and communicating to an employee how he or she is performing on the job, and ideally, establishing a plan of improvement. Penilaian prestasi kerja karyawan adalah proses untuk menentukan dan mengkomunikasikan kepada karyawan tentang bagaimana performanya dalam melakukan pekerjaannya dan idealnya, membuat rencana untuk membangun karSRiernya.

\section{Unsur-unsur Penilaian Prestasi Kerja}

Unsur-unsur penilaian prestasi kerja yaitu (Mangkunegara, 2000:85) :

1. Kerjasama, adalah kemampuan seseorang karyawan bersama-sama dengan orang lain dalam menyelesaikan tugas atau pekerjaan yang telah ditentukan sehingga mencapai daya guna dan hasil guna yang sebesar-besarnya.

2. Tanggung jawab, hal ini merupakan kesanggupan seorang karyawan atau pegawai dalam menyelesaikan tugas atau pekerjaan yang telah diserahkan kepada karyawan dengan sebaik-baiknya dan tindakan yang telah dilakukan.

3. Kepemimpinan, adalah kemampuan yang dimliki oleh seseorang untuk meyakinkan orang lain sehingga dapat digunakan secara maksimal untuk melaksanakan tugas pokok.

4. Kedisplinan, dapat diartikan sebagai suatu sikap menghormati, menghargai, patuh, dan taat pada peraturan yang berlaku baik secara tertulis ataupun tidak tertulis serta sanggup menjalankan dan tidak membantah untuk menerima sanksi-sanksi apabila melanggar tugas dan wewenang yang diberikan.

Menurut Lazer dan Wikstrom (1997) dalam Rivai (2006), unsur-unsur yang dinilai dibagi menjadi tiga yaitu: 
1. Kemampuan teknis, yaitu kemampuan menggunakan pengetahuan, metode, teknik dan peralatan yang dipergunakan untuk melaksanakan tugas serta pengalaman dan pelatihan yang diperolehnya.

2. Kemampuan konseptual, yaitu kemampuan untuk memahami kompleksitas perusahaan dan penyesuaian bidang gerak dari unit masing-masing ke dalam bidang operasional perusahaan secara menyeluruh, serta tanggung jawab sebagai seorang karyawan.

3. Kemampuan hubungan interpersonal, yaitu kemampuan untuk bekerja sama dengan orang lain, memotivasi karyawan, melakukan negosiasi dan lain-lain.

\section{Syarat-syarat Penilai}

Seorang penilai yang baik harus memiliki syarat-syarat sebagai berikut (Hasibuan, 2003:91) :

1. Untuk mendapatkan penilaian yang jujur, adil dan obyektif maka penilai haruslah orang yang mengerti tentang faktor-faktor yang menjadi indikator penilai.

2. Penilai harus tegas dan hendaknya mendasarkan penilaiannya pada benar atau salah, baik atau buruknya terhadap unsur-unsur yang dinilai sehingga penilaiannya jujur, adil, dan objektif.

3. Penilai harus mempunyai kewenangan formal supaya mereka dapat melaksanakan tugasnya dengan baik.

\section{Manfaat Penilaian Prestasi Kerja}

Menurut Handoko (1995:135) terdapat sepuluh manfaat yang dapat dipetik dari penilaian prestasi kerja tersebut sebagai berikut:

1. Perbaikan prestasi kerja. Umpan balik pelaksanaan kerja memungkinkan karyawan, manajer dan departemen personalia dapat memperbaiki kegiatan-kegiatan mereka demi perbaikan prestasi kerja.

2. Penyesuaian-penyesuaian kompensasi. Evaluasi prestasi kerja membantu para pengambil keputusan dalam menentukan kenaikan upah, pemberian bonus dan bentuk kompensasi lainnya.

3. Keputusan-keputusan penempatan. Promosi, transfer dan demosi biasanya didasarkan pada prestasi kerja masa lalu atau antisipasinya. Promosi sering merupakan bentuk penghargaan prestasi kerja masa lalu.

4. Kebutuhan-kebutuhan latihan dan pengembangan. Prestasi kerja yang jelek mungkin menunjukkan kebutuhan latihan. Demikian juga, prestasi yang baik mungkin mencerminkan potensi yang harus dikembangkan.

5. Perencanaan dan pengembangan karir. Umpan balik prestasi kerja seseorang karyawan dapat mengarahkan keputusan-keputusan karir, yaitu tentang jalur karir tertentu yang harus diteliti.

6. Penyimpangan-penyimpangan proses staffing. Prestasi kerja yang baik atau jelek mencerminkan kekuatan atau kelemahan prosedur staffing departemen personalia.

7. Ketidakakuratan informasional. Prestasi kerja yang jelek mungkin menunjukkan kesalahan dalam informasi analisis jabatan, rencana sdm, atau komponen-komponen sistem informasi manajemen personalia lainya. Menggantungkan diri pada informasi yang tidak akurat dapat mengakibatkan keputusan-keputusan personalia yang diambil menjadi tidak tepat.

8. Kesalahan-kesalahan desain pekerjaan. Prestasi kerja yang jelek mungkin merupakan suatu tanda kesalahan dalam desain pekerjaan. Penilaian prestasi membantu diagnose kesalahan-kesalahan tersebut.

9. Kesempatan kerja yang adil. Penilaian prestasi kerja secara akurat akan menjamin keputusan-keputusan penempatan internal diambil tanpa diskriminasi. 
10. Tantangan-tantangan eksternal. Kadang prestasi kerja dipengaruhi oleh faktor-faktor di luar lingkungan kerja, seperti; keluarga, kesehatan, kondisi finansial atau masalahmasalah pribadi lainya. Departemen personalia dimungkinkan untuk menawarkan bantuan kepada semua karyawan yang membutuhkan.

\section{Metode Penilaian Prestasi Kerja}

Menurut Robert Bacal (2002:116), ada tiga pendekatan yang paling sering dipakai dalam penilaian prestasi kerja karyawan:

1. Sistem Penilaian (rating system)

Sistem ini terdiri dari dua bagian, yaitu suatu daftar karakteristik, bidang, ataupun perilaku yang akan dinilai dan sebuah skala ataupun cara lain untuk menunjukkan tingkat kinerja dari tiap halnya. Perusahaan yang menggunakan sistem ini bertujuan untuk menciptakan keseragaman dan konsistensi dalam proses penilaian prestasi kerja. Kelemahan sistem ini adalah karena sangat mudahnya untuk dilakukan, para manajerpun jadi mudah lupa mengapa mereka melakukannya dan sistem inipun disingkirkannya.

2. Sistem Peringkat (ranking system)

Sistem peringkat memperbandingkan karyawan yang satu dengan yang lainnya. Hal ini dilakukan berdasarkan kriteria yang telah ditetapkan sebelumnya, misalnya: total pendapatan ataupun kemampuan manajemen. Sistem ini hampir selalu tidak tepat untuk digunakan, karena sistem ini mempunyai efek samping yang lebih besar daripada keuntungannya. Sistem ini memaksa karyawan untuk bersaing satu sama lain dalam pengertian yang sebenarnya. Pada kejadian yang positif, para karyawan akan menunjukkan kinerja yang lebih baik dan menghasilkan lebih banyak prestasi untuk bisa mendapatkan peringkat yang lebih tinggi. Sedangkan pada kejadian yang negatif, para karyawan akan berusaha untuk membuat rekan sekerja (pesaingnya) menghasilkan kinerja yang lebih buruk dan mencapai prestasi yang lebih sedikit dibandingkan dirinya.

3. Sistem berdasarkan tujuan (object-based system)

Berbeda dengan kedua sistem diatas, penilaian prestasi berdasarkan tujuan mengukur kinerja seseorang berdasarkan standar ataupun target yang dirundingkan secara perorangan. Sasaran dan standar tersebut ditetapkan secara perorangan agar memiliki fleksibilitas yang mencerminkan tingkat perkembangan serta kemampuan setiap karyawan.

\section{Faktor-faktor yang Mempengaruhi Penilaian Prestasi Kerja}

Ada berbagai faktor baik eksternal maupun internal yang akan mempengaruhi penilaian terhadap prestasi kerja karyawan (Tri, 2008:12 dalam Tajuddin, 2012)

1. Lingkungan Eksternal Organisasi

Lingkungan sekitar organisasi akan terus menempatkan tuntunan terhadap organisasi dan pegawainya untuk meningkatkan produktifitas kerjanya. Lingkungan akan semakin kompetitif dalam berbagai bidang, karena berbagai perubahan yang demikian pesatnya, sehingga adanya kinerja organisasi yang memiliki tingkat keunggulan kompetitif dan keunggulan komparatif akan menjadi suatu hal yang sangat penting. Tuntunan juga akan datang dari masyarakat. Oleh karena itu, penilaian prestasi kerja karyawan harus dilaksanakan secara teratur dan akurat.

2. Lingkungan Internal Organisasi.

Karakteristik masing-masing organisasi itu sendiri juga akan mempengaruhi penilaian prestasi kinerja karyawan. Dalam struktur organisasi akan menentukan siapa yang bertanggungjawab untuk menilai. Demikian pula dalam struktur organisasi yang menghargai rantai komando, sebagaimana dalam organisasi pemrintahan, maka yang menjadi atasan langsung pegawailah yang akan melakukan penilaian. Sedangkan 
dalam struktur yang menghargai komunikasi lateral, seperti dalam beberapa organisasi swasta besar, individu-individu. Selain itu, iklim organisasi, sifat dan karakter penilaiannya pun ikut mempengaruhi penilaian kinerja tersebut.

\section{Hambatan-hambatan Dalam Penilaian Prestasi Kerja}

Menurut Rao, T.V (1992:73) mengemukakan adanya bias atau kendala yang umumnya terjadi dalam penilaian prestasi kerja, yaitu:

1. Hallo Effect, terjadi karena penilai menyukai atau tidak menyukai sifat karyawan yang dinilainya. Oleh karena itu, cenderung akan memperoleh nilai positif pada semua aspek penilaian bagi karyawan yang disukainya. Begitu pula sebaliknya, seorang karyawan yang tidak disukainya akan mendapatkan nilai negatif pada semua aspek penilaian.

2. Liniency and Severity Effect, Liniency effect, yaitu penilaian cenderung beranggapan bahwa mereka harus berlaku baik terhadap karyawan, sehingga mereka cenderung memberi harkat (nilai) yang baik terhadap semua aspek penelitian. Sedangkan Severity effect, ialah penilai cenderung mempunyai falsafah dan pandangan yang sebaliknya terhadap karyawan sehingga cenderung akan memberikan nilai buruk.

3. Centeral tendency, yaitu penilai tidak ingin menilai terlalu tinggi dan juga tidak terlalu rendah kepada bawahannya (selalu berada di tengah-tengah) karena toleransi penilai yang terlalu berlebihan tersebut sehingga cenderung menilai sebagian besar dengan nilai yang rata-rata.

4. First impression error, yaitu penilai yang mengambil kesimpulan tentang karyawan berdasarkan kontak pertama mereka dan cenderung akan membawa kesan-kesan ini dalam penilaiannya hingga jangka waktu lama.

5. Recency effect, yaitu penilai cenderung memberikan nilai atas dasar perilaku yang baru saja mereka saksikan dan melupakan perilaku yang lalu selama jangka waktu tertentu.

\section{Pengertian Promosi Jabatan}

Pada dasarnya promosi jabatan merupakan salah satu bagian dari program penempatan yang dilaksanakan oleh perusahaan. Penempatan karyawan dilakukan dengan membuat penyesuaian terhadap kebutuhan perusahaan yang berhubungan dengan perencanaan untuk memperoleh orang yang tepat pada posisi yang tepat (the right man on the right place). Untuk memperoleh gambaran yang jelas mengenai promosi jabatan, berikut ini akan dikemukakan definisi-definisi mengenai promosi jabatan menurut beberapa ahli.

Menurut Hasibuan (2002:108) promosi jabatan berarti perpindahan yang memperbesar wewenang dan tanggung jawab ke jabatan yang lebih tinggi di dalam suatu organisasi yang diikuti dengan kewajiban, hak, status dan penghasilan yang lebih besar.

Menurut Siagian (2008:169) arti dari promosi jabatan itu sendiri adalah: apabila seorang pegawai dipindahkan dari satu pekerjaan ke pekerjaan lain yang tanggung jawabnya lebih besar, tingkatannya dalam hierarki jabatan lebih tinggi dan penghasilannya pun lebih besar pula.

Menurut Alex Nitisemito (1986:134) "Promosi adalah proses kegiatan pemindahan pegawai atau karyawan, dari satu jabatan atau tempat kepada jabatan atau tempat lain yang lebih tinggi serta diikuti oleh tugas, tanggung jawab, dan wewenang yang lebih tinggi dari jabatan yang diduduki sebelumnya. Dan pada umumnya promosi yang diikuti dengan peningkatan income serta fasilitas yang lain."

Pengertian promosi menurut Nitisemito semakin menegaskan bahwa promosi jabatan merupakan perpindahan jabatan ke jabatan yang lebih tinggi dengan tugas, tanggung jawab dan wewenang yang lebih tinggi, diiringi dengan peningkatan kompensasi dan fasilitas lain. Selain itu Nitisemito menambahkan bahwa promosi memiliki nilai lain sebagai sebuah pencapaian yang hendak dicapai oleh seseorang, yaitu berupa pengakuan yang antara lain prestasi kerja, kemampuan dan potensi yang dimilikinya untuk menduduki jabatan baru. (www.scribd.com/doc/16351016/Konsep-Promosi-Jabatan\#) 


\section{Tujuan Promosi Jabatan}

Hasibuan (2006:113) menjelaskan bahwa promosi jabatan dilakukan oleh perusahaan dengan tujuan sebagai berikut :

1. Untuk memberikan pengakuan, jabatan, dan imbalan jasa yang semakin besar kepada karyawan yang berprestasi kerja tinggi.

2. Dapat menimbulkan kepuasan dan kebanggan pribadi, status sosial yang lebih tinggi dan penghasilan yang semakin besar.

3. Untuk merangsang agar karyawan lebih bergairah kerja, disiplin tinggi dan memperbesar produktivitas kerjanya.

4. Untuk menjamin stabilitas kepegawaian dengan realisasinya promosi kepada karyawan dengan dasar dan pada waktu yang tepat serta penilaian yang jujur.

5. Kesempatan promosi dapat menimbulkan keuntungan berantai (multiplyer effect) dalam perusahaan karena menimbulkan lowongan berantai.

6. Memberikan kesempatan kepada karyawan untuk mengembangkan kreativitas dan inovasinya yang lebih baik dari keuntungan optimal perusahaan.

7. Untuk menambah/memperluas pengetahuan serta pengalaman kerja kepada para karyawan dan ini merupakan daya dorong bagi karyawan lainnya.

8. Untuk mengisi kekosongan jabatan karena pejabatnya berhenti, agar jabatan tidak kosong maka dipromosikan karyawan lainnya.

9. Karyawan yang dipromosikan kepada jabatan yang tepat dapat menumbuhkan semangat, kesenangan dan ketenangan dalam bekerja, sehingga dapat meningkatan produktivitas kerjanya.

10. Untuk mempermudah penarikan pelamaran sebab dengan adanya perangsang bagi pelamar-pelamar untuk memasukkan lamarannya.

\section{Manfaat Promosi Jabatan}

Menurut Simamora (1999:587) manfaat dari promosi jabatan adalah sebagai berikut:

a) Promosi jabatan memungkinkan perusahaan untuk mendayagunakan keahlian dan kemampuan karyawan setinggi mungkin.

b) Promosi jabatan seringkali diberikan mengimbali karyawan yang berkinerja sangat baik. Karyawan yang dihargai promosi jabatan akan termotivasi untuk memberikan kinerja yang lebih tinggi lagi jika mereka merasa bahwa kinerja yang efektif menyebabkan promosi jabatan.

c) Riset memperlihatkan bahwa kesempatan untuk promosi jabatan dan tingkat kepuasan kerja yang sangat tinggi berkolersi secara signifikan. Sistem promosi jabatan karyawan yang efektif dapat menyebabkan efesiensi organisasional yang lebih besar dan tingkat moral kerja karyawan yang tinggi.

Menurut Mangkuprawira (2004:196), promosi jabatan memiliki manfaat baik bagi perusahaan maupun karyawan, antara lain:

a) Promosi dapat memungkinkan perusahaan memanfaatkan kemampuan karyawan untuk memperluas usahanya.

b) Promosi dapat mendorong tercapainya kinerja karyawan yang baik. Karyawan umumnya berupaya melakukan pekerjaan sebaik mungkin jika mereka percaya bahwa kinerja tinggi mengarah pada adanya promosi.

c) Terdapat korelasi signifikan antara kesempatan untuk kenaikan pangkat dan tingkat kepuasan kerja.

\section{Dasar-dasar Promosi Jabatan}

Menurut Hasibuan (2003), dasar-dasar promosi jabatan dibagi menjadi 3 (tiga), yaitu sebagai berikut: 
1. Pengalaman (senioritas) dimana promosi jabatan kepada masa kerja dan pengalaman yang dimiliki oleh karyawan. Biasanya karyawan yang memiliki masa kerja yang cukup lama akan memiliki pengalaman yang lebih banyak.

2. Kecakapan dalam hal ini karyawan yang memiliki kecakapan mendapat prioritas untuk dipromosikan kepada jabatan yang lebih tinggi. Kecakapan yang dimaksud adalah kecakapan dalam hal pelaksanaan prosedur kerja yang praktis, teknik-teknik khusus dan disiplin ilmu pengetahuan, kecakapan dalam menyatukan dan menyelaraskan elemen-elemen yang terkait dalam penyusunan kebijakan manajemen dan kecakapan dalam memberikan motivasi secara langsung.

3. Kombinasi pengalaman dan kecakapan. Promosi ini didasarkan kepada lamanya dinas, ijazah pendidikan formal yang dimiliki dan hasil ujian kenaikan golongan.

\section{Syarat-syarat Promosi Jabatan}

Menurut Siagian (2009), syarat-syarat promosi adalah sebagai berikut:

1. Pengalaman

Dengan pengalaman yang lebih banyak diharapkan kemampuan yang lebih tinggi, ide-ide yang lebih banyak dan sebagainya.

2. Tingkat pendidikan

Ada juga perusahaan yang mensyaratkan minimal pendidikan untuk dapat dipromosikan pada jabatan tertentu. Alasannya adalah bahwa dengan pendidikan yang lebih tinggi diharapkan pemikiran yang lebih baik.

3. Loyalitas

Dengan loyalitas yang tinggi dapat diharapkan antara lain tanggung jawab yang lebih besar.

4. Kejujuran

Untuk promosi jabatan-jabatan tertentu mungkin masalah kejujuran merupakan syarat yang penting. Misalnya untuk jabatan kasir pada umumnya syarat kejujuran merupakan syarat utama yang harus diperhatikan.

5. Tanggung jawab

Kadang-kadang sering kali suatu perusahaan diperlukan suatu tanggung jawab yang cukup besar, sehingga masalah tanggung jawab merupakan syarat utama untuk promosi jabatan.

6. Kepandaian bergaul

Misalnya jabatan untuk salesman adalah sangat penting untuk menetapkan kepandaian bergaul sebagai suatu syarat promosi jabatan.

7. Prestasi kerja

Pada umumnya setiap perusahaan selalu mencantumkan syarat untuk prestasi kinerjanya.

8. Inisiatif dan kreatif

Untuk syarat promosi jabatan terhadap jabatan tertentu, mungkin syarat tingkat inisiatif dan kreatif merupakan syarat yang harus diperhatikan. Hal ini disebabkan karena untuk jabatan tersebut sangat diperlukan inisiatif dan kreatif.

\section{Jenis-jenis Promosi Jabatan}

Pada prakteknya, ternyata ada beberapa bentuk promosi jabatan, Hasibuan (2006:113) menyebutkan bahwa setidaknya ada 4 (empat) jenis promosi jabatan, yaitu :

1. Promosi Sementara (Temporary Promotion)

Seseorang yang mengalami kenaikan jabatan untuk sementara karena adanya jabatan yang lowong yang harus sesegera mungkin diisi.

2. Promosi Tetap (Permanent Promotion) 
Seseorang yang dipromosikan dari suatu jabatan ke jabatan yang lebuh tinggi karena karyawan tersebut telah memenuhi syarat untuk dipromosikan. Sifat promosi ini adalah tetap, dimana wewenang, tanggung jawab dan gaji akan mengalami kenaikan.

3. Promosi Kecil (Small Promotion)

Menaikan jabatan seseorang dari jabatan yang dinilai tidak terlalu sulit untuk dipindahkan ke jabatan yang lebih sulit yang membutuhkan keterampilan dan kualifikasi tertentu, tetapi tidak disertai dengan peningkatan wewenang, tanggung jawab serta kenaikan gaji.

4. Promosi Kering (Dry Promotion)

Seseorang dinaikkan jabatannya ke jabatan yang lebih tinggi disertai dengan peningkatan pangkat, wewenang dan tanggung jawab tetapi tidak disertai dengan kenaikan gaji atau upah.

Perlu dikemukakan bahwa tidak semua pegawai mau dipromosikan. Kadang-kadang ada pegawai yang menolak mendapat promosi dengan beberapa alasan tertentu. Alasanalasan tersebut menurut Hasibuan (2006:114) :

a. Perbedaan kenaikan gaji dengan yang diterima mungkin dianggap tidak seimbang dengan tanggung jawab yang akan dilaksanakan.

b. Karyawan segan untuk meninggalkan kelompok lamanya untuk masuk ke dalam kelompok baru yang belum pasti sikap penerimanya.

c. Keamanan pada pekerjaan yang baru selalu ada faktor-faktor ketidakpastian sedangkan pada pekerjaan yang lama mereka telah mempunyai keahlian dan telah menguasainya.

d. Keluarga tidak bersedia pindah ke tempat yang baru karena melihat banyak hal yang tidak sesuai dari tempat yang baru, seperti pendidikan maupun fasilitas lainnya.

e. Kesehatan sehingga tidak dapat memikul tanggung jawab yang semakin besar. Iklim yang tidak cocok, dan seringnya wabah penyakit melanda.

f. Lokasi baru merupakan wilayah terpencil sehingga untuk mendapatkan saran dan fasilitas tertentu sangatlah sulit. Misalnya sarana pendidikan, transportasi, hiburan, rumah sakit. Serta adat istiadat dan bahasa di tempat baru yang tidak cocok.

\section{Penelitian Terdahulu}

Menurut penelitian yang dilakukan oleh Zubaidah dan Ira Yuliana (2017) yang berjudul Pengaruh Penilaian Prestasi Kerja Dan Kedisiplinan Terhadap Promosi Jabatan PT. Batamec Shipyard, dalam Jurnal Akuntansi dan Bisnis (Akmenbis) Akademi Akuntansi Permata Harapan, hasil penelitian ini menunjukkan variabel kebijakan Pengaruh Prestasi Kerja dan Kedisiplinan Terhadap Promosi Jabatan secara positif dan signifikan berpengaruh terhadap Promosi Jabatan karyawan PT. Batamec Shipyard, atas dasar pengujian T dan uji F di dalam pengujian normalisasi menunjukkan sebesar 62.0\% Prestasi Kerja dan Kedisiplinan berpengaruh terhadap Promosi Jabatan, dan nilai R Square $385=38.5 \%$ mencerminkan hubungan erat antar variabel X1 dan X2 sangat erat hubungannya terhadap variabel $\mathrm{Y}$. Dengan mengetahui hubungan antara variabel-variabel ini, Prestasi Karyawan dan Disiplin Karyawan dapat digunakan untuk meningkatkan karir dan dipromosikan pada PT. Batamec Shipyard.

Menurut penelitian yang dilakukan oleh Hanum et all (2015) dengan judul Analisis Pengaruh Penilaian Prestasi Kerja Dan Kompetensi Karyawan Terhadap Promosi Jabatan (Studi Kasus Pada Koperasi Jasa Usaha Bersama Pertambangan Timah) dalam Jurnal Ilmiah Progresif Manajemen Bisnis (JIPMB), Vol.5 No.2 yang diterbitkan pada bulan November 2015, Tujuan dari penelitian ini adalah untuk mengetahui pengaruh Penilaian Prestasi Kerja dan Kompetensi Karyawan Terhadap Promosi Jabatan pada Koperasi Jasa Usaha Bersama Pertambangan Timah. Penelitian ini menggunakan sampel sebanyak 56 responden dan pengumpulan data dengan menggunakan kuesioner beserta studi pustaka dan diuji dengan 
metode analisis data komputer. Hipotesis diuji dengan menggunakan uji t dan uji f dalam kerangka Analisis Regresi Ganda termasuk Koefisien Determinasi untuk membuktikan kemampuan variabel-variabel Independen menjelaskan dan memprediksi variabel dependen. Hasil penelitian menunjukkan bahwa Koefisien Determinasi $\mathrm{R}^{2}=0,852$, yang berarti pengaruh Penilaian Prestasi Kerja dan Kompetensi Karyawan secara simultan memiliki hubungan positif yang kuat terhadap Promosi Kerja. Dengan kata lain, hasil dari penelitian ini dapat didefinisikan jika Penilaian Penilaian Prestasi Kerja dan Kompetensi Karyawan, secara parsial maupun simultan dapat menjelaskan dan memprediksi Promosi Jabatan sebesar $85,2 \%$. Nilai yang tersisa yaitu $14,8 \%$ dijelaskan oleh variabel lain yang tidak termasuk dalam penelitian ini.

Menurut penelitian oleh Syamsir (2017), dengan judul Pengaruh Penilaian Pretsasi Kerja Karyawan Terhadap Promosi Jabatan Pada PT Bosowa Propertindo dalam Jurnal Riset Edisi XV Unibos Makassar. Vol.3 No.004 yang dipublikasikan pada bulan April 2017, adalah untuk mengetahui pengaruh penilaian kinerja karyawan terhadap promosi jabatan pada PT Bosowa Propertindo. Objek penelitian ini adalah PT Bosowa Propertindo. Alat analisis yang digunakan adalah analisis deskriptif dan analisis regresi linier berganda. Hasil penelitian menunjukkan bahwa penilaian kinerja karyawan (kemampuan, disiplin, kepribadian dan tanggung jawab) memiliki pengaruh yang signifikan terhadap promosi jabatan. ini dapat diketahui dengan persamaan $\mathrm{Y}=2,229+0,379 \mathrm{X} 1+0,158 \mathrm{X} 2+0,306 \mathrm{X} 3+(-0,016) \mathrm{X} 4$ dan nilai $\mathrm{R}$ square sebesar 0,592 atau sama dengan 59,2\% yang berarti prestasi kerja (kemampuan, disiplin, kepribadian dan tanggung jawab) pengaruh terhadap promosi Posisi $59,2 \%$. Sedangkan sisanya $(100 \%-59,2 \%=40,8 \%)$ dipengaruhi oleh variabel lain di luar model regresi ini.

Sedangkan menurut penelitian yang dilakukan oleh Yuni Andriani (2018) yang berjudul Pengaruh Penilaian Prestasi Kerja Karyawan Terhadap Promosi Jabatan Pada PT. Noor Asni Naga Jaya (Rayon Ilir) Samarinda yang dipublikasikan dalam eJournal Administrasi Bisnis, penelitian ini menggunakan pendekatan kuantitatif. Populasi dan sampel penelitian yang digunakan peneliti adalah seluruh karyawan PT. Noor Asni Naga Jaya (Rayon Ilir) Samarinda yang berjumlah 61 responden. Metode pengumpulan data menggunakan angket dan dokumentasi. Uji coba instrumen menggunakan uji validitas dan uji reliabilitas. Teknik analisis data menggunakan analisis regresi linier sederhana, koefisien korelasi, koefisien determinasi dan pengujian hipotesis (uji $\mathrm{F}$ atau uji Simultan). Hasil regresi adalah $\mathrm{Y}=1,372+0,464 \mathrm{X}+\mathrm{e}$. Dimana bahwa jika penilaian prestasi kerja konstan atau $\mathrm{X}=$ [0, maka promosi jabatan sebesar 1,372 dan $b=0,464$ menunjukkan bahwa setiap penilaian prestasi kerja, akan mendorong promosi jabatan sebesar 0,464, determinasi $\left(\mathrm{R}^{2}\right)$ adalah 0,230 . Hal ini menunjukkan bahwa sebesar $23 \%$ promosi jabatan karyawan dapat dijelaskan oleh variabel penilaian prestasi kerja, sedangkan sisanya $77 \%$ dijelaskan atau dipengaruhi oleh faktor-faktor lain yang tidak diteliti dalam penelitian ini. Uji F dilakukan untuk mengetahui variabel-variabel bebas (Penilaian Prestasi Kerja) terhadap variabel terikat (Promosi Jabatan) pada PT. Noor Asni Naga Jaya (Rayon Ilir) Samarinda dari uji $F_{\text {hitung }}$ sebesar 17,630 sedangkan $\mathrm{F}_{\text {tabel }}$ sebesar 0,2126 ( $\left.\mathrm{F}_{\text {hitung }}>\mathrm{F}_{\text {tabel }}\right)$. Artinya terdapat pengaruh positif dan signifikan dari Penilaian Prestasi Kerja terhadap Promosi Jabatan.

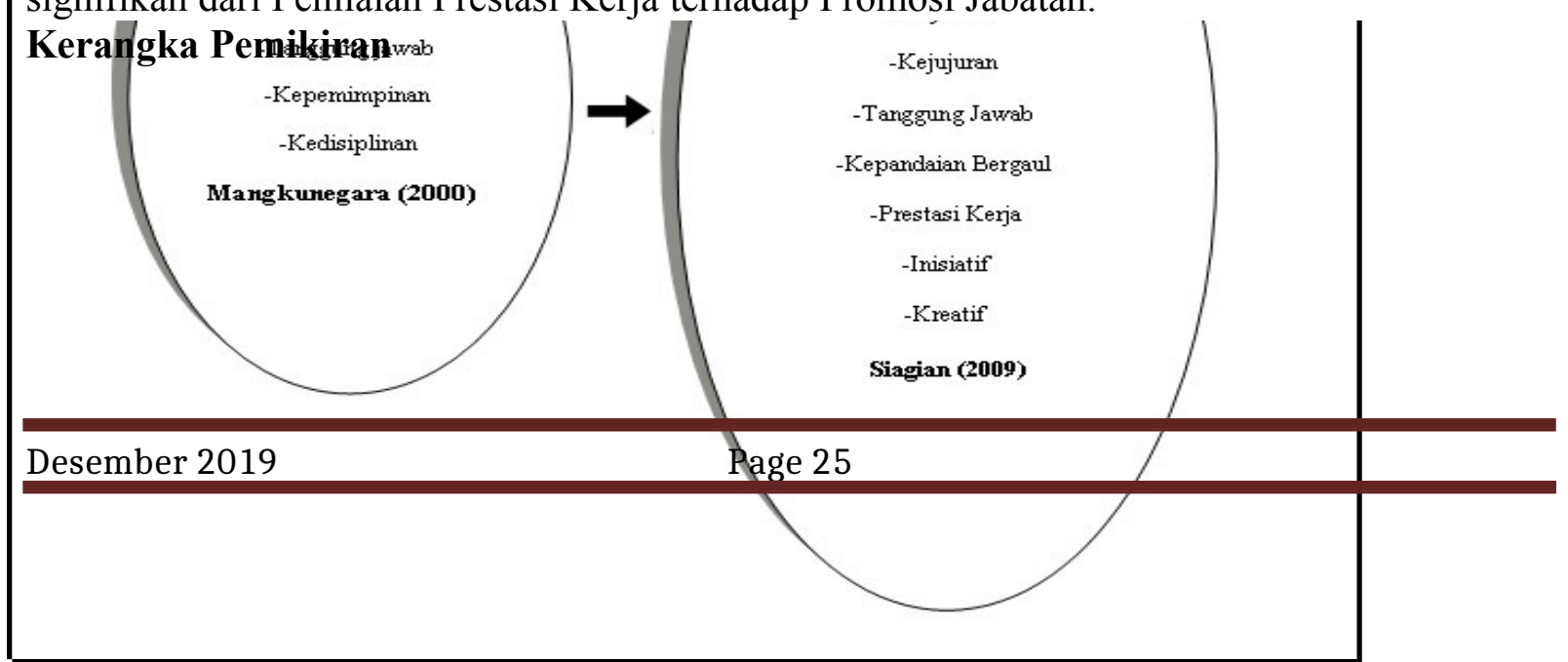




\section{Gambar Kerangka Pemikiran}

Penelitian ini mencoba melihat pengaruh penilaian prestasi kerja $(\mathrm{X})$ sebagai variabel bebas terhadap promosi jabatan (Y) sebagai variabel terikat. Variabel X didefinisikan melalui indikator-indikator yang dikemukakan oleh Mangkunegara (2000) yaitu antara lain: kerjasama, tanggung jawab, kepemimpinan, dan kedisiplinan. Untuk variabel Y didefinisikan melalui indikator-indikator yang dikemukakan Siagian (2009) yaitu antara lain: pengalaman, tingkat pendidikan, loyalitas, kejujuran, tanggung jawab, kepandaian bergaul, prestasi kerja, inisiatif dan kreatif.

\section{Hipotesis}

Penelitian ini menggunakan hipotesis asosiatif, yaitu jawaban sementara terhadap rumusan masalah asosiatif, yaitu yang menanyakan hubungan antara dua variabel atau lebih. (Sugiyono, 2015 :103). Dalam penelitian ini, hipotesis asosiatif tersebut dapat dirumuskan sebagai berikut:

1. Ho : $\beta<0$ artinya variabel penilaian prestasi kerja $(\mathrm{X})$ tidak berpengaruh signifikan terhadap variabel promosi jabatan $(\mathrm{Y})$

2. Ha : $\beta \geq 0$ artinya variabel penilaian prestasi kerja $(\mathrm{X})$ berpengaruh signifikan terhadap variabel promosi jabatan (Y)

\section{Metode Penelitian}

\section{Desain Penelitian}

Penelitian menggunakan metode penelitian kuantitatif asosiatif dengan tujuan untuk mengkaji dan melihat hubungan antara penilaian prestasi kerja karyawan terhadap promosi jabatan pada PT. Bank Bukopin,Tbk Cabang Palembang.

\section{Populasi dan Sampel}

Populasi dalam penelitian ini adalah seluruh karyawan tetap yang ada di PT. Bank Bukopin,Tbk Cabang Palembang sebanyak 88 orang, yang terbagi menjadi 2 unit kerja, yaitu Unit Operasional sebanyak 41 orang dan Unit Bisnis sebanyak 47 orang. Karyawan perempuan berjumlah 38 orang dan laki-laki berjumlah 50 orang.

Teknik sampling dalam penelitian ini dilakukan dengan teknik nonprobability sampling dengan metode sampling purposive, yaitu teknik penentuan sampel dengan pertimbangan tertentu yang bertujuan agar data yang diperoleh nantinya bisa lebih representatif. (Sugiyono, 2015:124). Karena keterbatasan waktu dan biaya, sampel yang digunakan adalah hanya karyawan tetap pada kantor cabang utama PT. Bank Bukopin,Tbk 
Palembang unit Bisnis dan Operasional, memiliki masa kerja minimal 2 tahun dan yang berlokasi di jalan Kapten A Rivai, yang berjumlah sekitar 30 orang.

\section{DAFTAR SAMPEL KARYAWAN PT. BANK BUKOPIN KANTOR CABANG UTAMA RIVAI PALEMBANG}

\begin{tabular}{|c|c|c|}
\hline No. & UNIT KERJA & JUMLAH KARYAWAN \\
\hline 1 & $\begin{array}{l}\text { Koordinator (Koordinator Layanan } \\
\text { Nasabah, Koordinator Layanan Kredit) }\end{array}$ & 2 Orang \\
\hline 2 & $\begin{array}{l}\text { Staf Layanan Nasabah Senior (Head } \\
\text { Teller, Customer Service) \& Staf } \\
\text { Layanan Nasabah Junior (Teller, Back } \\
\text { Office) }\end{array}$ & 12 Orang \\
\hline 3 & Staf Legal & 1 Orang \\
\hline 3 & $\begin{array}{l}\text { Staf Supporting Kredit (Administrasi } \\
\text { Kredit, Administrasi Laporan) }\end{array}$ & 4 Orang \\
\hline 5 & Staf Investigasi Kredit & 1 Orang \\
\hline 5 & Staf SDM & 1 Orang \\
\hline 5 & $\begin{array}{l}\text { Staf Utilities Senior (Sistem Operasi } \\
\text { Komputer) \& Staf Utilities Junior } \\
\text { (Sarana Logistik) }\end{array}$ & 2 Orang \\
\hline 6 & $\begin{array}{l}\text { Marketing (Account Officer \& } \\
\text { Relationship Banking Officer) }\end{array}$ & 7 Orang \\
\hline \multicolumn{2}{|r|}{ Total } & 30 Orang \\
\hline
\end{tabular}

Sumber : PT. Bank Bukopin,Tbk Cabang Palembang

\section{Teknik Pengumpulan Data}

Data yang digunakan pada penelitian ini merupakan data primer dengan metode pengumpulan data menggunakan insrumen kuesioner (angket). Bentuk instrumen yang digunakan dalam penelitian ini adalah checklist karena lebih praktis dan hemat. Jawaban setiap item instrumen yang menggunakan skala Likert mempunyai gradasi dari sangat positif sampai sangat negatif, yang berupa kata-kata antara lain :

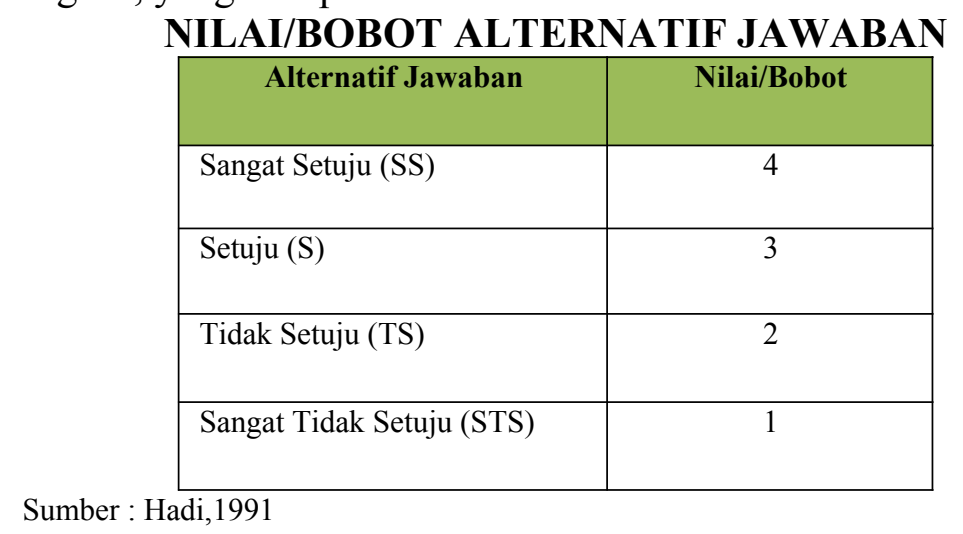

Penulis tidak menggunakan alternatif jawaban Ragu-ragu. Hal ini dilakukan untuk menghilangkan jawaban responden yang bersifat ragu-ragu. Tersedianya alternatif jawaban di tengah membuat kecenderungan responden memilih alternatif jawaban di tengah, terutama bagi responden yang ragu-ragu. Jawaban di tengah tersebut akan menghilangkan banyak data penelitian, sehingga mengurangi informasi yang dapat diambil dari responden (Hadi, 1991).

DAFTAR PERTANYAAN KUESIONER 


\begin{tabular}{|c|c|}
\hline No & PERNYATAAN \\
\hline \multicolumn{2}{|r|}{ Penilaian Prestasi Kerja (X) } \\
\hline 1. & $\begin{array}{l}\text { Anda mampu untuk bekerja sama dengan orang lain untuk menyelesaikan pekerjaan } \\
\text { yang diberikan. }\end{array}$ \\
\hline 2. & Anda mampu mengerjakan tugas pribadi tanpa meminta bantuan karyawan lain. \\
\hline 3. & $\begin{array}{l}\text { Anda tidak pernah memiliki konflik dengan teman sekerja yang berhubungan dengan } \\
\text { jabatan anda sekarang. }\end{array}$ \\
\hline 4. & Anda lebih menyukai melakukan pekerjaan yang tidak berhubungan dengan orang lain. \\
\hline 5. & Anda mampu menyelesaikan semua pekerjaan yang dibebankan tepat waktu. \\
\hline 6. & Anda tidak pernah melakukan kesalahan yang dapat mempengaruhi kinerja perusahaan. \\
\hline 7. & Anda selalu dapat mencapai target pekerjaan yang dibebankan kepada anda. \\
\hline 8. & Anda selalu dapat menyelesaikan pekerjaan apa pun halangan yang ada. \\
\hline 9. & $\begin{array}{l}\text { Anda dapat mendelegasikan pekerjaan pada bawahan anda tanpa kekhawatiran akan } \\
\text { pekerjaan itu. }\end{array}$ \\
\hline 10 & $\begin{array}{l}\text { Bawahan anda selalu mengikuti instruksi yang anda berikan tanpa pertanyaan yang } \\
\text { berarti. }\end{array}$ \\
\hline 11 & Anda mampu mengarahkan bawahan untuk mencapai hasil yang anda inginkan. \\
\hline 12 & Pekerjaan yang diberikan atasan akan langsung anda kerjakan saat itu juga. \\
\hline 13 & Anda tidak pernah terlambat datang ke kantor. \\
\hline 14 & Anda tidak pernah mendapatkan surat peringatan dari atasan. \\
\hline 15 & Anda tidak pernah melakukan negosiasi yang berkaitan dengan peraturan perusahaan. \\
\hline \multicolumn{2}{|r|}{ Promosi Jabatan } \\
\hline No & PERNYATAAN \\
\hline 1. & $\begin{array}{l}\text { Pengalaman dalam pekerjaan yang sekarang anda lakukan, mampu membuat anda } \\
\text { menyelesaikan pekerjaan sesuai target walau banyak halangannya. }\end{array}$ \\
\hline 2. & Anda mampu meminimalisir halangan pada pekerjaan anda sekarang. \\
\hline 3. & $\begin{array}{l}\text { Anda bersedia untuk bersekolah lagi, bila perusahaan mengharapkan tingkat pendidikan } \\
\text { yang lebih tinggi dari pendidikan anda sekarang. }\end{array}$ \\
\hline 4. & $\begin{array}{l}\text { Tingkat pendidikan anda sekarnag mencukuoi syarat untuk mendapatkan posisi yang } \\
\text { lebih baik dari yang anda tempati saat ini. }\end{array}$ \\
\hline 5. & $\begin{array}{l}\text { Anda berniat pindah ke perusahaan yang menawarkan posisi yang lebih baik dari yang } \\
\text { anda tempati saat ini. }\end{array}$ \\
\hline
\end{tabular}




\begin{tabular}{|c|l|}
\hline 6. & Anda merasa perusahaan telah memberikan yang terbaik sesuai dengan pekerjaan anda. \\
\hline 7. & Anda akan mengakui bila telah membuat kesalahan. \\
\hline 8. & $\begin{array}{l}\text { Bila anda menemukan dompet di jalan, maka anda akan segera mengembalikan kepada } \\
\text { pemiliknya bila terdapat alamat di dalamnya. }\end{array}$ \\
\hline 9. & $\begin{array}{l}\text { Anda sering merasa perusahaan memberikan tanggung jawab yang lebih besar bila } \\
\text { dibandingkan dengan penghasilan yang diterima setiap bulannya. }\end{array}$ \\
\hline 10 & $\begin{array}{l}\text { Anda bersedia untuk lembur bila pekerjaan anda belum terselesaikan pada hari itu, } \\
\text { sedangkan atasan mengharapkan hasil dari pekerjaan anda. }\end{array}$ \\
\hline 11 & Anda mempunyai banyak teman di luar dari pekerjaan anda. \\
\hline 12 & Anda termasuk orang yang mudah mendapatkan teman dalam waktu singkat. \\
. & $\begin{array}{l}\text { Anda sering mendapatkan pujian dari atasan atas pekerjaan yang anda lakukan. } \\
.\end{array}$ \\
\hline 14 & $\begin{array}{l}\text { Anda sering mendapatkan pujian dari sesama karyawan atas pekerjaan yang anda } \\
\text { lakukan. }\end{array}$ \\
\hline 15 & $\begin{array}{l}\text { Anda merasa memiliki kreatifitas dan inisiatif agar target pekerjaan anda dapat selalu } \\
\text { tercapai. }\end{array}$ \\
\hline
\end{tabular}

\section{Teknik Analisis Data}

Dalam penelitian ini alat yang digunakan untuk menganalisis data adalah SPSS for windows versi 24.0. SPSS (Statistical Package for Sosial Sciences) adalah sebuah program komputer yang digunakan untuk menganalisa sebuah data dengan analisis statistik. Untuk menguji layak atau tidaknya suatu instrumen penelitian diperlukan pengujian sebagai berikut :

\section{Uji Validitas}

Uji validitas adalah suatu teknik analisis data yang digunakan untuk mengukur seberapa kuat hubungan suatu variabel dengan variabel lainnya. Uji validitas adalah uji yang dilakukan untuk memastikan kemampuan sebuah skala untuk mengukur konsep yang dimaksud. Menurut Sugiyono (2015:363) validitas merupakan derajat ketepatan antara data yang terjadi pada obyek penelitian dengan data yang dapat dilaporkan oleh peneliti.

Manfaat dari uji validitas yaitu untuk mengetahui apakah item-item yang teruji dari kuesioner benar-benar mampu mengungkapkan dengan pasti apa yang akan diteliti. Pengujian ini dilakukan dengan mengajukan butir-butir pertanyaan kuesioner yang nantinya akan diberikan kepada responden. Instrumen kuesioner telah valid dan dapat digunakan dalam penelitian jika nilai signifikansi lebih besar dari nilai alpha (Nilai pada Sig. (2-tailed) > 0,05).

Uji Reliabilitas

Uji reliabilitas adalah tingkat kestabilan suatu alat pengukur dalam mengukur suatu gejala atau kejadian. Semakin tinggi reliabilitas suatu alat pengukur, semakin stabil pula alat pengukur tersebut untuk mengukur suatu gejala dan sebaliknya jika reliabilitas tersebut rendah maka alat tersebut tidak stabil dalam mengukur suatu gejala. Dengan penggunaan tingkat alpha dengan rumus (Sudjana,1982).

Uji reliabilitas dimaksudkan untuk mengukur sampai sejauh mana derajat ketepatan, ketelitian atau keakuratan yang ditunjukkan oleh instrumen pengukuran (Husein Umar,1999). Dengan menggunakan SPSS for windows versi 23.0, analisis atas butirbutir pertanyaan/pernyataan pada kuesioner,dapat dinyatakan bahwa intrumen $\mathrm{X}$ dan $\mathrm{Y}$ 
memiliki tingkat reliabilitas yang tinggi jika nilai koefisien yang diperoleh (nilai Cronbach's Alpha) lebih besar dari 0,6 (Imam Ghozali, 2002)

Analisis Regresi Linear Sederhana

Metode untuk mengolah dan menganalisa digunakan model persamaan Regresi Linear Sederhana (dengan satu prediktor) atau satu variabel independen (Sugiyono, 2015:262). Model regresi linear dapat digunakan untuk melakukan prediksi seberapa tinggi nilai variabel dependen bila nilai variabel independen dimanipulasi atau diubah-ubah. Analisis Regresi Sederhana ini bertujuan untuk menguji pengaruh antara variabel $\mathrm{X}$ terhadap variabel Y. Bentuk model regresi sederhana adalah sebagai berikut.

Keterangan :

$$
Y=\alpha+\beta x+e
$$

$$
\begin{aligned}
& Y=\text { Promosi Jabatan } \\
& \alpha=\text { Konstanta atau bila harga } X=0 \\
& \beta=\text { Koefisien regresi } \\
& X=\text { Prestasi Kerja } \\
& e=\text { error term }
\end{aligned}
$$

Uji Asumsi Klasik

Pada penelitian ini digunakan uji asumsi klasik yang berupa : Uji Normalitas. Pengujian normalitas adalah pengujian tentang kenormalan distribusi data. (Ashari \& Santoso, 2005). Dalam penelitian ini menggunakan uji Kolmogorov-Smirnov dengan pedoman sebagai berikut :

1. Ho diterima jika p-value pada kolom Asymp.Sig (2-tailed) $>$ level of significant $(\alpha$ $=0,05)$, sebaliknya Ha ditolak.

2. Ho diterima jika p-value pada kolom Asymp.Sig (2-tailed) $<$ level of significant $(\alpha$ $=0,05)$, sebaliknya Ho diterima. (Nugroho, 2005).

\section{Uji Hipotesis (Uji t)}

Ketepatan fungsi regresi sampel dalam menaksir nilai aktual dapat diukur dari nilai koefisien determinasi $\left(\mathrm{R}^{2}\right)$, dan nilai statistik t. Perhitungan statistik disebut signifikan secara statistik apabila nilai uji statistiknya berada dalam daerah kritis (dimana Ho ditolak), sebaliknya disebut tidak signifikan bila nilai uji statistiknya berada dalam daerah dimana Ho diterima (Imam Ghozali, 2002).

Pada penelitian ini uji hipotesis akan dilakukan dengan uji t. Seperti sudah dibahas sebelumnya, bahwa hipotesis dalam penelitian ini dirumuskan sebagai berikut :

1. Ho : $\beta<0$ artinya variabel prestasi kerja $(\mathrm{X})$ tidak berpengaruh signifikan terhadap variabel promosi jabatan $(\mathrm{Y})$

2. Ha : $\beta \geq 0$ artinya variabel prestasi kerja $(\mathrm{X})$ berpengaruh signifikan terhadap variabel promosi jabatan $(\mathrm{Y})$.

Kriteria keputusan dari hipotesis di atas adalah sebagai berikut :

1. Jika $t_{\text {hitung }}>\mathrm{t}_{\text {tabel}}$, maka Ho ditolak, dan sebaliknya Ha diterima

2. Jika $t_{\text {hitung }} \leq \mathrm{t}_{\text {tabel}}$, maka Ho diterima, dan sebaliknya Ha ditolak.

Berdasarkan taraf signifikansi 0,05 atau taraf kepercayaan 95\% dengan derajat kebebasan $(\mathrm{dk})=\mathrm{N}-2$.

\subsection{Koefisien Determinasi $\left(\mathbf{R}^{2}\right)$}

Koefisien determinasi $\left(\mathrm{R}^{2}\right)$ bertujuan untuk mengetahui seberapa besar kemampuan variabel independen menjelaskan variabel dependen. Nilai $R$ square dikatakan baik jika diatas 0,5 karena nilai $\mathrm{R}$ square berkisar antara $0-1$ (Buono Agung Nugroho, 2005).

\section{Hasil Dan Pembahasan Karakteristik Responden}


Vol. 2 No. 2 Desember 2019, 15-40

\section{Karakteristik Responden Berdasarkan Jenis Kelamin}

\begin{tabular}{|c|c|c|}
\hline $\begin{array}{c}\text { Jenis } \\
\text { Kelamin }\end{array}$ & Frekuensi & Dalam Persentase \\
\hline Pria & 14 & $46,67 \%$ \\
\hline Wanita & 16 & $53,33 \%$ \\
\hline TOTAL & 30 & $100,00 \%$ \\
\hline
\end{tabular}

Sumber : Hasil Pengolahan data primer, 2018

Berdasarkan data deskriptif dari Tabel dapat diketahui bahwa persentase responden yang berjenis kelamin pria sebanyak 14 orang dengan persentase sebesar 46,67\%, sedangkan wanita sebanyak 16 orang dengan persentase sebesar 53,33\% menunjukkan bahwa sebagian besar responden dalam penelitian ini adalah wanita.

\section{Karakteristik responden berdasarkan usia}

\begin{tabular}{|c|c|c|}
\hline Usia & Frekuensi & $\begin{array}{c}\text { Dalam } \\
\text { Persentase }\end{array}$ \\
\hline$<25$ tahun & 1 & $3,33 \%$ \\
\hline $25-40$ tahun & 22 & $73,33 \%$ \\
\hline $41-55$ tahun & 7 & $23,33 \%$ \\
\hline TOTAL & 30 & $100,00 \%$ \\
\hline
\end{tabular}

Sumber : Hasil Pengolahan data primer, 2018

Dari Tabel menunjukkan bahwa responden yang terbanyak dalam penelitian ini adalah responden yang berusia antar 25 - 40 sebanyak 22 orang dengan persentase sebesar $73,33 \%$.

\section{Karakteristik Responden Berdasarkan Tingkat Pendidikan}

\begin{tabular}{|c|c|c|}
\hline $\begin{array}{c}\text { Tingkat } \\
\text { Pendidikan }\end{array}$ & Frekuensi & $\begin{array}{c}\text { Dalam } \\
\text { Persentas } \\
\text { e }\end{array}$ \\
\hline SMU/SMK & 0 & $0,00 \%$ \\
\hline D3 & 10 & $33,33 \%$ \\
\hline S1 & 19 & $63,33 \%$ \\
\hline S2 & 1 & $3,33 \%$ \\
\hline TOTAL & 30 & $100,00 \%$ \\
\hline
\end{tabular}

Sumber : Hasil Pengolahan data primer, 2018

Dari Tabel menunjukkan bahwa responden yang terbanyak dalam penelitian ini adalah responden dengan tingkat pendidikan S1 sebanyak 19 responden dengan persentase sebesar $63,33 \%$.

Masa kerja dipandang sebagai lamanya seseorang bekerja dalam perusahaan dan pengalaman yang diperoleh selama masa kerja tersebut. Masa kerja tidak hanya menunjukkan waktu tetapi juga soal perolehan tambahan pengetahuan, kemampuan dan ketrampilan. Semakin lama karyawan bekerja maka akan semakin berpengalaman orang tersebut dalam bekerja.

\section{Karakteristik Responden Berdasarkan Masa Kerja}


Vol. 2 No. 2 Desember 2019, 15-40

\begin{tabular}{|c|c|c|}
\hline Masa Kerja & Frekuensi & $\begin{array}{c}\text { Dalam } \\
\text { Persentase }\end{array}$ \\
\hline$<2$ tahun & 0 & $0,00 \%$ \\
\hline $2-5$ tahun & 10 & $33,33 \%$ \\
\hline $6-10$ tahun & 10 & $33,33 \%$ \\
\hline$>10$ tahun & 10 & $33,33 \%$ \\
\hline TOTAL & 30 & $100,00 \%$ \\
\hline
\end{tabular}

Sumber : Hasil Pengolahan data primer, 2018

Berdasarkan data deskriptif dari Tabel dapat diketahui bahwa persentase responden dengan masa kerja kurang dari 2 (dua) tahun tidak ada dalam penelitian ini, sedangkan responden dengan masa kerja antara $2-5$ tahun, $6-10$ tahun dan masa kerja lebih dari 10 tahun berbagi frekuensi masing-masing sebanyak 10 responden dengan persentase sebesar $33,33 \%$.

Karakteristik Responden Berdasarkan Unit Ke
\begin{tabular}{|c|c|c|}
\hline Unit Kerja & Frekuensi & $\begin{array}{c}\text { Dalam } \\
\text { Persentase }\end{array}$ \\
\hline Operasional & 23 & $76,67 \%$ \\
\hline Bisnis & 7 & $23,33 \%$ \\
\hline TOTAL & 30 & $100,00 \%$ \\
\hline
\end{tabular}

Sumber : Hasil Pengolahan data primer, 2018

Dari Tabel menunjukkan bahwa responden yang terbanyak dalam penelitian ini adalah responden dari unit kerja operasional sebanyak 23 responden dengan persentase sebesar $76,67 \%$.

\section{Identifikasi Jawaban Responden}

\section{Variabel Penilaian Prestasi Kerja}

Hasil analisis frekuensi deskriptif untuk tanggapan responden terhadap variabel penilaian prestasi kerja yang terdiri atas 15 item pernyataan. Dari 15 item pernyataan, hampir semua pernyataan mendapat respon positif dari responden, secara keseluruhan variabel penilaian prestasi kerja berada pada kategori cukup baik. Secara rinci ditampilkan pada tabel 4.6.

Persentase item variabel penilaian prestasi kerja $(x)$

(\%)

\begin{tabular}{|c|c|c|c|c|c|}
\hline Item & SS & S & TS & STS & Total \\
\hline 1 & 46,67 & 53,33 & 0,00 & 0,00 & 100,00 \\
\hline 2 & 36,67 & 60,00 & 3,33 & 0,00 & 100,00 \\
\hline 3 & 10,00 & 50,00 & 40,00 & 0,00 & 100,00 \\
\hline 4 & 3,33 & 53,33 & 26,67 & 16,67 & 100,00 \\
\hline 5 & 10,00 & 80,00 & 6,67 & 3,33 & 100,00 \\
\hline 6 & 3,33 & 60,00 & 36,67 & 0,00 & 100,00 \\
\hline 7 & 10,00 & 70,00 & 16,67 & 3,33 & 100,00 \\
\hline 8 & 20,00 & 66,67 & 13,33 & 0,00 & 100,00 \\
\hline 9 & 3,33 & 66,67 & 23,33 & 6,67 & 100,00 \\
\hline
\end{tabular}




\begin{tabular}{|c|c|c|c|c|c|}
\hline 10 & 6,67 & 53,33 & 33,33 & 6,67 & 100,00 \\
\hline 11 & 10,00 & 70,00 & 16,67 & 3,33 & 100,00 \\
\hline 12 & 13,33 & 80,00 & 6,67 & 0,00 & 100,00 \\
\hline 13 & 43,33 & 43,33 & 13,33 & 0,00 & 100,00 \\
\hline 14 & 50,00 & 26,67 & 23,33 & 0,00 & 100,00 \\
\hline 15 & 6,67 & 53,33 & 33,33 & 6,67 & 100,00 \\
\hline
\end{tabular}

Sumber : Hasil Pengolahan data primer, 2018

\section{Variabel Promosi Jabatan}

Hasil analisis frekuensi deskriptif untuk tanggapan responden terhadap variabel promosi jabatan yang terdiri atas 15 item pernyataan. Dari 15 item pernyataan, hampir semua pernyataan mendapat respon positif dari responden, secara keseluruhan variabel promosi jabatan berada pada kategori cukup baik. Secara rinci ditampilkan pada tabel.

\section{Persentase item variabel promosi jabatan $(y)$}

(\%)

\begin{tabular}{|c|c|c|c|c|c|}
\hline Item & SS & S & TS & STS & Total \\
\hline 1 & 20,00 & 73,33 & 6,67 & 0,00 & 100,00 \\
\hline 2 & 16,67 & 83,33 & 0,00 & 0,00 & 100,00 \\
\hline 3 & 20,00 & 66,67 & 10,00 & 3,33 & 100,00 \\
\hline 4 & 13,33 & 56,67 & 26,67 & 3,33 & 100,00 \\
\hline 5 & 23,33 & 46,67 & 26,67 & 3,33 & 100,00 \\
\hline 6 & 10,00 & 60,00 & 26,67 & 3,33 & 100,00 \\
\hline 7 & 13,33 & 83,33 & 3,33 & 0,00 & 100,00 \\
\hline 8 & 33,33 & 63,33 & 3,33 & 0,00 & 100,00 \\
\hline 9 & 26,67 & 43,33 & 30,00 & 0,00 & 100,00 \\
\hline 10 & 36,67 & 56,67 & 6,67 & 0,00 & 100,00 \\
\hline 11 & 43,33 & 50,00 & 6,67 & 0,00 & 100,00 \\
\hline 12 & 46,67 & 36,67 & 16,67 & 0,00 & 100,00 \\
\hline 13 & 6,67 & 50,00 & 40,00 & 3,33 & 100,00 \\
\hline 14 & 3,33 & 60,00 & 33,33 & 3,33 & 100,00 \\
\hline 15 & 23,33 & 56,67 & 20,00 & 0,00 & 100,00 \\
\hline \multicolumn{5}{|c|}{ Sumber : Hasil Pengolahan data primer, 2018 }
\end{tabular}

\section{Uji Hipotesis}

\section{Uji Validitas}

Uji Validitas digunakan untuk menguji apakah instrumen pertanyaan/pernyataan dalam kuesioner sudah valid. Berikut ini tabel output hasil Uji Validitas dengan menggunakan program SPSS versi 23.0.

HASIL UJI VALIDITAS

Correlations

\begin{tabular}{|ll|r|r|}
\hline & $\begin{array}{c}\text { Promosi } \\
\text { Jabatan }\end{array}$ & $\begin{array}{c}\text { Penilaian } \\
\text { Prestasi } \\
\text { Jabatan }\end{array}$ \\
\hline Promosi Jabatan & Pearson & 1 &, $740^{* *}$ \\
& Correlation & &, 0 \\
& Sig. (2-tailed) & 30 & 01 \\
& $\mathrm{~N}$ &, $740 * *$ & 30 \\
\hline Penilaian Prestasi & Pearson &, 0 & \\
Jabatan & Correlation & 01 & \\
& Sig. (2-tailed) & 30 & 30 \\
\hline
\end{tabular}


** Correlation is significant at the 0.01 level (2-tailed)

Berdasarkan hasil uji validitas menunjukkan bahwa seluruh hasil nilai R (korelasi) adalah signifikan (terdapat tanda bintang pada angka pearson correlation) dengan nilai signifikansi lebih kecil dari nilai alpha (Nilai pada Sig. (2-tailed) < 0,05). Dengan demikian instrumen kuesioner telah valid dan dapat digunakan dalam penelitian.

\section{Uji Reliabilitas}

Uji Realibilitas dilakukan untuk menguji apakah instrumen pertanyaan/pernyataan dalam kuesioner sudah reliabel (sudah layak/sesuai dengan dimensi indikator variabel). Uji Realibilitas dilakukan pada setiap variabel.

\section{Uji Reliabilitas Variabel Y}

Berikut ini tabel output hasil Uji Realibilitas untuk variabel Y dengan menggunakan program SPSS versi 23.0

\begin{tabular}{|c|r|}
\multicolumn{2}{c|}{ Reliability Statistics } \\
\hline $\begin{array}{c}\text { Cronbach's } \\
\text { Alpha }\end{array}$ & N of Items \\
\hline, 727 & 15 \\
\hline
\end{tabular}

Berdasarkan hasil uji reliabilitas untuk variabel Y, didapati hasil bahwa butir-butir pertanyaan/pernyataan pada kuesioner untuk variabel $\mathrm{Y}$ telah reliabel dan dapat digunakan dalam penelitian. Hal ini terlihat dari nilai Cronbach's Alpha yang lebih besar dari 0,6 $(0,727>0,6)$

\section{Uji Reliabilitas Variabel $\mathrm{X}$}

Berikut ini tabel output hasil Uji Realibilitas untuk variabel $\mathrm{X}$ dengan menggunakan program SPSS versi 23.0

\begin{tabular}{|c|c|}
\hline \multicolumn{2}{|c|}{ Reliability Statistics } \\
\hline $\begin{array}{c}\text { Cronbach's } \\
\text { Alpha }\end{array}$ & $\mathrm{N}$ of Items \\
\hline, 680 & 15 \\
\hline
\end{tabular}

Berdasarkan hasil uji reliabilitas untuk variabel $\mathrm{X}$, didapati hasil bahwa butir-butir pertanyaan/pernyataan pada kuesioner untuk variabel $\mathrm{X}$ telah reliabel dan dapat digunakan dalam penelitian. Hal ini terlihat dari nilai Cronbach's Alpha yang lebih besar dari 0,6 $(0,680>0,6)$.

\section{Uji Asumsi Klasik}

Uji asumsi klasik merupakan uji yang menjadi prasyarat awal sebelum melakukan analisis regresi. Dalam penelitian ini, uji asumsi klasik yang digunakan adalah uji normalitas. Uji normalitas bertujuan untuk melihat apakah data tersebar secara normal atau tidak. Uji normalitas pada penelitian ini menggunakan Uji Kolmogorov-Smirnov.

One-Sample Kolmogorov-Smirnov Test

\begin{tabular}{|ll|r|r|}
\hline & & $\begin{array}{c}\text { Promosi } \\
\text { Jabatan }\end{array}$ & $\begin{array}{c}\text { Penilaian } \\
\text { Prestasi } \\
\text { Kerja }\end{array}$ \\
\hline $\mathrm{N}$ & Mean & 45,37 & 30 \\
Normal Parameters $^{\mathrm{a}, \mathrm{b}}$ & 39,60 \\
& Std. & 4,255 & 3,673 \\
& Deviation &, 178 &, 157 \\
Most Extreme & Absolute &, 178 &, 157 \\
Differences & Positive &,- 086 &,- 132 \\
& Negative &, 178 &, 157 \\
Test Statistic & &, $170^{\mathrm{c}}$ &, $158^{\mathrm{c}}$ \\
Asymp. Sig. (2-tailed) & & &
\end{tabular}

a. Test distribution is Normal.

b. Calculated from data. 
c. Lilliefors Significance Correction.

d. This is a lower bound of the true significance.

Berdasarkan Tabel Uji Kolmogorov Smirnov di atas terlihat bahwa nilai Asymp. Sig. (2-tailed) setiap variabel lebih besar dari nilai alpha (Asymp. Sig. (2-tailed) > 0,05). Hal ini berarti dapat disimpulkan bahwa data telah tersebar secara normal.

\section{Analisis Regresi}

Analisis Regresi digunakan untuk melihat pengaruh variabel bebas $(\mathrm{X})$ dan variabel terikat (Y).

\section{Koefisien Determinasi $\left(\mathbf{R}^{2}\right)$}

Secara teori nilai $\mathrm{R}^{2}$ menggambarkan seberapa besar variabel bebas mempengaruhi besarnya variabel terikat. Nilai $\mathrm{R}^{2}$ sebaiknya lebih besar dari 0,6 (60 persen).

Model Summary
\begin{tabular}{|l|c|l|l|c|}
\hline Model & $\mathrm{R}$ & R Square & $\begin{array}{c}\text { Adjusted R } \\
\text { Square }\end{array}$ & $\begin{array}{c}\text { Std. } \\
\text { Error of } \\
\text { the } \\
\text { Estimate }\end{array}$ \\
\hline 1 &, $840^{\mathrm{a}}$ &, 720 &, 715 & 4,287 \\
\hline
\end{tabular}
a. Predictors: (Constant), Penilaian Prestasi Kerja
b. Dependent Variable: Promosi Jabatan

Berdasarkan hasil analisis regresi di atas terlihat bahwa nilai $\mathrm{R}^{2}$ ( $R$ Square) adalah 0,720 ini artinya bahwa variabel-variabel bebas berpengaruh terhadap variabel terikat sebesar 72 persen. Sementara sisanya 28 persen dipengaruhi variabel lain di luar model.

\section{Uji Parsial (Uji t)}

Analisis Uji t bertujuan untuk mengetahui apakah variabel promosi kerja dipengaruhi oleh variabel penilaian prestasi karyawan secara parsial atau sendiri-sendiri. Adapun hasil analisis tersebut dapat dilihat pada tabel berikut ini.

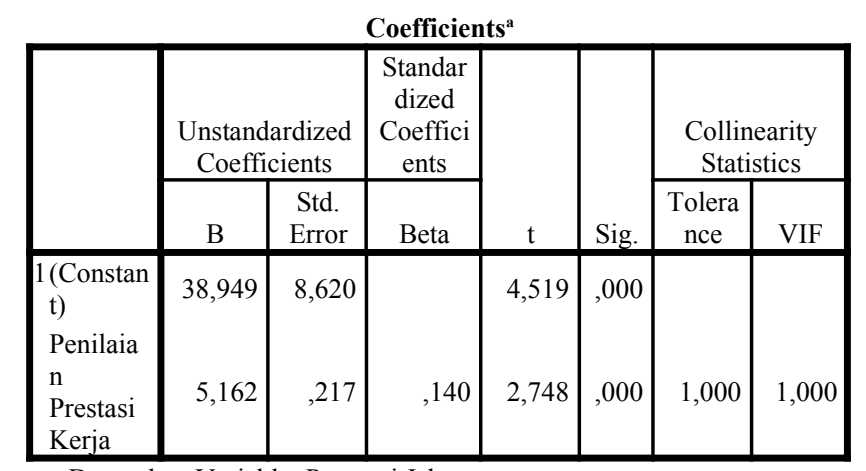

a. Dependent Variable: Promosi Jabatan

Berdasarkan hasil regresi di atas maka model regresi yang diperoleh adalah:

$$
\mathrm{Y}=38,949+5,162 \mathrm{X}+\mathrm{e}
$$

Nilai $t_{\text {hitung }}$ untuk $X$ adalah sebesar 2,748 dengan nilai signifikansi (Sig.) adalah sebesar 0,000 . Nilai signifikansi tersebut lebih kecil dari nilai alpha $(0,00<0,05)$. Hal ini berarti variabel $X$ berpengaruh signifikan terhadap variabel $\mathrm{Y}$.

Uji $t$ juga dapat dilakukan dengan membandingkan nilai $t_{\text {hitung }}>t_{\text {tabel }}$. Nilai $t_{\text {tabel }}$ dapat dilihat pada tabel distribusi $\mathrm{t}$ dengan ketentuan $\alpha=0,05, \mathrm{~N}=30, \mathrm{k}=2$ sehingga nilai degree of freedom adalah $28(\mathrm{Df}=\mathrm{N}-\mathrm{k}=28)$. Nilai $\mathrm{t}_{\text {tabel }}$ yang didapat adalah 2,048. Nilai $\mathrm{t}_{\text {hitung }}>\mathrm{t}_{\text {tabel }}$ $(2,748>2,048)$. Dengan demikian maka variabel $\mathrm{X}$ berpengaruh signifikan terhadap variabel Y.

\section{Pembahasan}

Pengaruh Sistem Penilaian Prestasi Kerja terhadap Promosi Jabatan 
Hasil penelitian mengenai pengaruh sistem penilaian prestasi kerja terhadap promosi jabatan pada PT. Bank Bukopin,Tbk Kantor Cabang Palembang menunjukkan bahwa sistem penilaian prestasi kerja ini berpengaruh positif terhadap promosi jabatan, yang terlihat dari hasil regresi yang diperoleh dalam $\mathrm{Y}=38,949+0,162 \mathrm{x}+\mathrm{e}$, dengan nilai $\mathrm{t}_{\text {hitung }}$ variabel $\mathrm{X}$ sebesar 2,748. Nilai $t_{\text {hitung }}$ ini lebih besar dari $t_{\text {tabel }}(2,748>2,048)$ yang menunjukkan bahwa variabel $\mathrm{X}$ yaitu sistem penilaian prestasi kerja di Bank Bukopin Cabang Palembang berpengaruh secara signifikan terhadap variabel $Y$ yaitu promosi jabatan. Jadi hipotesis atas penelitian ini $\mathrm{Ha}: \beta>0$ yang artinya variabel prestasi kerja $(\mathrm{X})$ berpengaruh dan signifikan dan positif terhadap variabel promosi jabatan (Y) terbukti.

Pada PT. Bank Bukopin,Tbk Cabang Palembang penilaian prestasi kerja dilakukan secara terbuka dimana atasan akan memanggil bawahannya untuk membahas hasil kerja karyawan yang bersangkutan. Cara ini dimaksudkan agar proses penilaian kinerja ini sekaligus sebagai sarana bagi karyawan dan atasan, dan sebaliknya untuk membahas bagaimana sebenarnya prestasi kerja karyawan yang bersangkutan. Hal-hal yang merupakan kelebihan dan kelemahan karyawan tersebut. Selain dari atasan langsung karyawan yang melakukan penilaian prestasi kerja karyawan, Personnel Committee Bank Bukopin juga melakukan hal yang sama. Personnel Committee ini adalah forum yang membahas masalah kepegawaian di Bank Bukopin. Personnel Committee ini terdiri dari Personnel Committee Cabang (PCC), Personnel Committee Direktorat (PCD), Personnel Committee Pusat (PCP). PCC beranggotakan pejabat-pejabat senior di cabang yang bersangkutan yang ditunjuk untuk melakukan penilaian.

Hasil akhir dari keseluruhan program evaluasi yang dibuat dalam rangka penilaian kerja (Performance Appraisal/PA) ditetapkan dalam Indeks Prestasi Kerja (IPK). IPK ini dibagi menurut unit kerja masing-masing, misalnya PA Bisnis, PA Supporting dan PA Operasional. Penilaian performance unit Bisnis di PT. Bank Bukopin,Tbk Cabang Palembang, secara umum dilihat dari aspek kualitatif dan aspek kuantitatif. Pada aspek kuantitatif ini mencakup pencapaian anggaran, pertumbuhan volume usaha, pencapaian rasiorasio dan produktifitas. Namun bagi AO (Account Officer) dan RBO (Relationship Banking Officer) juga dinilai aspek lainnya yang meliputi aspek manajerial, perilaku, penugasan khusus (faktor penambah) maupun Catatan Negatif (faktor pengurang). Aspek perilaku yang dinilai disini antara lain kejujuran/integritas, disiplin, tanggung jawab, komunikasi dan kreativitas/inovasi. Sedangkan yang dimaksud dengan Catatan Negatif adalah pelanggaran yang dilakukan karyawan terhadap peraturan kerja dan peraturan-peraturan lainnya.

Penilaian Parameter Kinerja Supporting (PA Supporting) mencakup aspek Financial (Pencapaian Target Profit Before Tax/TPBT), Customer, Business Process, Tingkat Kepatuhan dan Manajemen Risiko, Learning and Growth (Tingkat Penguatan Budaya Perusahaan), Aspek Manajerial dan Tingkat Pencapaian Employee Turn Over dan Pengembangan Karyawan). Pada penilaian aspek Customer dilihat dari tingkat kepuasan nasabah internal terhadap layanan yang diberikan, juga dilihat dari kecepatan dan ketepatan layanan yang diberikan oleh staf yang dinilai. Sedangkan pada Internal Business Process atau Pelaksana Program Kerja Rutin berdasarkan beberapa hal antara lain zero defect, kelengkapan tugas, kecepatan, akurasi data dan informasi, dan ketepatan waktu.

Pada Penilaian Performance unit Operasional merupakan evaluasi yang dilakukan atas semua aspek operasional diluar bidang perkreditan, baik kuantitatif maupun kualitatif. Beberapa komponen yang menjadi sumber penilaian unit operasional ini, diantaranya Kepatuhan Terhadap Peraturan (KTP), produktivitas, follow up masalah, pengiriman data laporan yang akurat dan tepat waktu, support pelayanan terhadap bisnis, efisiensi, perilaku, dan faktor penambah (Pelaksanaan Tugas Khusus) dan faktor pengurang (Catatan Negatif). Aspek perilaku yang dinilai pada unit Operasional ini meliputi : kejujuran/integritas, disiplin, tanggung jawab pada tugas, komunikasi, kreatifitas dan inovasi. 
Menurut PT. Bank Bukopin,Tbk yang dimaksud dengan promosi jabatan bukan hanya perpindahan karyawan dari jabatan dengan tingkat jabatan job level tertentu kepada jabatan dengan tingkat jabatan job level lebih tinggi saja, tetapi perpindahan karyawan dari jabatan dengan tingkat jabatan job level tertentu kepada tingkat jabatan job level yang sama namun dengan tanggung jawab pekerjaan yang lebih besar juga termasuk promosi, contohnya Manajer pada Cabang kelas 3 dengan job level 11 menjadi Pemimpin Cabang kelas 4 dengan job level 11 memiliki kewenangan dan tanggung jawab yang lebih luas.

Penilaian prestasi kerja di Bank Bukopin disebut dengan Performance Appraisal (PA), sangat berpengaruh terhadap pertimbangan promosi jabatan karyawan. Hasil PA karyawan dinilai selama 2 (dua) tahun terakhir. Karyawan yang dipromosikan nilai PA minimal B dan B (Baik dan Baik), atau dalam 3 (tiga) tahun terakhir nilai PA minimal 2 B dan 1 CB (Baik dan Baik, dan 1 Cukup Baik), baru karyawan tersebut dapat dipromosikan. Hal ini sesuai dengan hasil pada penelitian, dimana prestasi kerja berpengaruh positif terhadap promosi jabatan di PT. Bank Bukopin,Tbk. Ditunjukkan oleh nilai $\mathrm{R}^{2}$ sebesar 0,720 yang berarti bahwa penilaian prestasi kerja berpengaruh sebesar 72 persen terhadap promosi jabatan.

PT. Bank Bukopin,Tbk juga menerapkan penilaian prestasi kerja untuk promosi jabatan berdasarkan penilaian terhadap perilaku karyawan yaitu kejujuran/integritas, disiplin, tanggung jawab pada tugas yang dipercayakan sesuai fungsi dan jabatan yang dipegang, juga aspek kemampuan dalam berkomunikasi dengan pihak eksternal serta kemauan untuk berinteraksi secara positif, dan aspek kreatifitas dan inovasi agar dapat memenuhi kebutuhan "customer" sesuai dengan perkembangan selera, teknologi, komunikasi dan lainnya. Akan tetapi, disamping sistem penilaian prestasi kerja yang akan mempengaruhi promosi jabatan seorang karyawan, Bank Bukopin juga memiliki beberapa pertimbangan dalam hal promosi jabatan. Beberapa pertimbangan tersebut antara lain :

1. Status karyawan tetap.

2. Tersedianya lowongan/informasi jabatan dan sesuai dengan kebutuhan perusahaan.

3. Hasil penilaian PA karyawan minimal Baik dan Baik selama 2 (dua) tahun.

4. Hasil assesment/penilaian kompetensi dan potensi untuk berkembang sesuai tugastugas dalam jabatan baru bagi promosi pada jabatan-jabatan tertentu jika diperlukan.

5. Mempunyai kondite yang baik (tidak mempunyai catatan negatif) :

a. Dalam hal sebelum dipromosikan terdapat catatan negatif berupa SP atas sanksi pelanggaran fraud maka dapat dipromosikan yang lebih tinggi minimal berjarak 2 (dua) tahun sejak diberlakukannya SP kepada karyawan yang bersangkutan atau

b. Dalam hal terdapat catatan negatif berupa SP I, II dan III non fraud, maka dapat dipromosikan ke jenjang yang lebih tinggi minimal berjarak 1 (satu) tahun atau setelah selesainya periode sanksi dalam hal periode sanksi lebih dari 1 (satu) tahun sejak diberlakukannya SP kepada karyawan yang bersangkutan.

\section{Kesimpulan}

6. Pertimbangan kondisi kesehatan (khusus untuk jabatan manajerial).

Berdasarkan hasil analisis yang dilakukan pada taraf signifikansi 5, maka kesimpulan yang dapat dikemukakan dalam penelitian ini adalah sebagai berikut :

1. Penelitian ini juga memberikan nilai $t_{\text {hitung }}$ untuk variabel $X$ adalah sebesar 2,748 yang berarti nilai $t_{\text {hitung }}>t_{\text {tabel }}(2,748>2,048)$. Dengan demikian variabel sistem penilaian prestasi kerja berpengaruh secara signifikan terhadap promosi jabatan pada PT. Bank Bukopin, Tbk Cabang Palembang.

2. PT. Bank Bukopin,Tbk Cabang Palembang memadukan dua unsur penilaian prestasi kerja yaitu kerjasama, tanggung jawab, kepemimpinan, kedisiplinan, dengan kemampuan teknis (pengetahuan, metode, teknik dan peralatan), kemampuan konseptual (memahami kompleksitas perusahaan dan penyesuaian bidang gerak dari 
unit masing-masing), kemampuan hubungan interpersonal (kemampuan bekerjasama dengan orang lain dan melakukan negosiasi) dimana melalui Indeks Prestasi Kerja (IPK) dapat dinilai Performance Appraisal (PA) masing-masing karyawan sesuai dengan unit kerjanya.

3. Hasil penelitian diperoleh nilai $\mathrm{R}^{2}$ adalah sebesar 0,720 . Ini berarti bahwa sistem penilaian prestasi kerja di Bank Bukopin Cabang Palembang berpengaruh terhadap promosi jabatan sebesar 72 .

4. Karyawan yang dapat dipromosikan harus memiliki nilai PA minimal 2B (Baik dan Baik) selama 2 (dua) tahun berturut-turut, atau dalam 3 (tiga) tahun terakhir nilai PA minimal 2B (Baik dan Baik) dan 1 CB (Cukup Baik) baru dapat dipromosikan.

5. Faktor pertimbangan lain dalam rangka promosi jabatan di PT. Bank Bukopin,Tbk Cabang Palembang sebesar 28 dipengaruhi oleh ada tidaknya lowongan atau informasi jabatan yang dituju/level lebih tinggi dan mempunyai kondite yang baik (tidak memiliki catatan negatif).

\section{DAFTAR PUSTAKA}

Arikunto, Suharsimi. Prosedur Penelitian Suatu Pendekatan Praktik. Rineka Cipta. Jakarta: 2006.

Andriani, Yuni. Pengaruh Penilaian Prestasi Kerja Karyawan Terhadap Promosi Jabatan Pada PT. Noor Asni Naga Jaya (Rayon Ilir) Samarinda. Vol.6 No.1. eJournal Administrasi Bisnis. 2018.

Ashari. Purbayu dan Budi Santoso. Analisis Statistik dengan Microsoft Excel dan SPSS. Andi Offset. Yogyakarta: 2005.

Bacal, Robert. Performance Management. PT Gramedia Pustaka Utama. Jakarta: 2002.

Bangun. Manajemen Sumber Daya Manusia. Bandung: 2012.

Bank Bukopin,Tbk. SK Penyempurnaan Mutasi Karyawan No.1022. 2017.

Bank Bukopin,Tbk. SK Direksi, Pedoman Parameter Penilaian Kinerja Karyawan No.478. 2007.

Bank Bukopin,Tbk. SK Direksi, Penyempurnaan Struktur Organisasi Bank Bukopin No.0805. 2018

Byars, Lloyd L dan Leslie W. Rue. Human Resources Management, International Edition. Irwin-McGraw-Hill. New York USA: 2000.

Cressida, Farda Dewi; Al-Musadieq \& Hakam, Soe'oed. PENGARUH PRESTASI KERJA KARYAWAN TERHADAP PROMOSI JABATAN (Studi pada Karyawan Bank Sumsel Babel Cabang Kapten A. Rivai Palembang). Universitas Brawijaya. Malang: 2013. Skripsi tidak dipublikasikan.

Flippo, E. B. Manajemen Personalia. Edisi Keenam. Penerbit Erlangga, Jakarta: 1996.

Ghozali, Imam. Aplikasi Analisis Multivariat dengan Program SPSS. Badan Penerbit Universitas Diponegoro. Semarang: 2002.

Griffin, R. Business, 8th Edition. Prentice Hall. NJ: 2006.

Hadi, S. Metodologi Research. Yayasan Penerbitan Fakultas Psikologi Universitas Gajah Mada. Yogyakarta: 1991.

Hanum, Regitha, Rizal R Manullang dan Aslinda. Analisis Pengaruh Penilaian Prestasi Kerja Dan Kompetensi Karyawan Terhadap Promosi Jabatan (Studi Kasus Pada Koperasi Jasa Usaha Bersama Pertambangan Timah). Vol.5 No.2. Jurnal Ilmiah Progresif Manajemen Bisnis (JIPMB) : 2015.

Hasibuan, Malayu. Manajemen SDM. Edisi Revisi. PT. Bumi Aksara. Jakarta: 2002

Hasibuan, Malayu. Manajemen Sumber Daya Manusia. PT. Bumi Aksara. Jakarta: 2003.

Hasibuan, Malayu. Dasar-Dasar Perbankan. Bumi Aksara. Jakarta: 2004. 
Hasibuan, Malayu S. P. Manajemen Sumber Daya Manusia. PT. Bumi Aksara. Jakarta: 2006.

Hamid, Abdul. Pengaruh Penilaian Prestasi Kerja Karyawan Terhadap Promosi

Jabatan pada PT Bank Central Asia. Sekolah Tinggi Manajemen Transpor Trisakti. Jakarta: 2010.

https://id.wikipedia.org/wiki/Manajemen_sumber_daya_manusia Diakses pada tanggal 11 April 2018 pukul 23.45 wib.

http://www.bukopin.co.id/ Diakses pada tanggal 11 April 2018 pukul 00.05 wib.

https://www.scribd.com/doc/16351016/Konsep-Promosi-Jabatan\# (Konsep Promosi Jabatan. Diakses pada tanggal 11 Oktober 2017 pukul 01.55 wib)

Kidder Louise, Research Methods in Social Relation. Holt, Rinehart and Winston. 1981.

Mangkunegara, Anwar Prabu. Evaluasi Kinerja SDM. Relika Aditama. Bandung: 2000.

Mangkunegara, Anwar Prabu. Manajemen Sumber Daya Manusia Perusahaan. PT. Remaja Rosda Karya. Bandung: 2002.

Mangkuprawira, Tb. Sjafri. Manajemen Sumber Daya Manusia Strategik. Ghalia Indonesia. Jakarta: 2004.

Nitisemito, Alex. Manajemen Personalia: Manajemen Sumber Daya Manusia. Ghalia Indonesia. Jakarta: 1986.

Nugroho. Buono Agung. Strategi Jitu Memilih Metode Statistik Penelitian dengan SPSS. Andi Yogyakarta. Jakarta: 2005.

Purwaningsih, Amalia \& Betty Magdalena. Pengaruh Senioritas Dan Prestasi Kerja Terhadap Promosi Jabatan Pada Karyawan. Vol.3 No.1. Jurnal Bisnis Darmajaya. 2017.

Pratiwi, Maretha Arjani. PENGARUH PENILAIAN PRESTASI KERJA DAN PROMOSI TERHADAP MOTIVASI KERJA KARYAWAN PADA PT. INTI (PERSERO) BANDUNG. Universitas Komputer Indonesia. Bandung: 2014.

Rao T,V. Penilaian Prestasi Kerja: teori dan praktek. Pustaka Binaman Pressindo. Jakarta: 1992.

Rivai, Vetzel. Manajemen Sumber Daya Manusia Untuk Perusahaan. Grafindo Persada. Jakarta: 2006.

Siagian, Sondang P. Manajemen Sumber Daya Manusia. Bumi Aksara. Jakarta: 2008.

Siagian, Sondang P. Manajemen Sumber Daya Manusia. Edisi 3. Bumi Aksara. Jakarta: 2009.

Siagian, Sondang P. Kiat Meningkatkan Produktivitas Kerja. PT Rineka Cipta. Jakarta: 2009.

Sugiyono. Metode Penelitian Bisnis. ALFABETA. Bandung: 2004.

Sugiyono. Metode Penelitian Kuantitatif Kualitatif Dan R\&D. ALFABETA. Bandung : 2009.

Sugiyono. Metode Penelitian Kualitatif Kuantitatif Kombinasi Mixed Methods. Cetakan Ke Empat, Alfabeta. Bandung: 2013.

Sugiyono. Metode Penelitian Pendidikan Pendekatan Kuantitatif, Kualitatif, dan R\&D. ALFABETA. Bandung: 2015.

Sudjana, Nana. Metode Statistika. Tarsito. Bandung: 1982.

Simamora, Henry. Manajemen Sumber Daya Manusia. Edisi ke-2, Cetakan Kedua. Bagian Penerbitan STIE YKPN. Yogyakarta: 1999.

Supranto. Metode Penelitian. Jakarta: 1987.

Sutopo, H.B. Penelitian Kualitatif: Dasar Teori dan Terapannya dalam Penelitian. Universitas Sebelas Maret. Surakarta: 2006.

Suwatno, TjutjuYuniarsih. Manajemen Sumber Daya Manuasia. Alfabeta,CV. Bandung: 2016. 
Syamsir. Pengaruh Penilaian Prestasi Kerja Karyawan Terhadap Promosi Jabatan Pada PT Bosowa Propertindo. Vol.3 No.004. Jurnal Riset Edisi XV Unibos Makassar: 2017.

T. Hani Handoko, Manajemen Sumber daya Manusia. BPFE, Yogyakarta: 1995.

Tajuddin, Sukma Juwati. Pengaruh Penilaian Prestasi Kerja Karyawan Terhadap Promosi Jabatan pada PT. Semen Tonasa Kabupaten Pangkep. Universitas Hasanuddin. 2012.

Terry, George R. Prinsip-prinsip Manajemen. Bumi Aksara, Jakarta: 2006.

Umar, Husein. Metodologi Penelitian Aplikasi dalam Pemasaran. Edisi II. PT. Gramedia Pustaka Utama. Jakarta: 1999.

Umar, Husein. Metode Penelitian Untuk Skripsi dan Tesis Bisnis. Cetakan ke-6, PT. RajaGrafindo Persada. Jakarta: 2004.

Umar, Husein. Metode Penelitian Untuk Skripsi dan Tesis Bisnis. Gramedia Pustaka Utama. Jakarta: 2011.

Werther, William B. dan Davis, Keith (Werther dan Davis, 1996:261) http://newcampuran.blogspot.co.id/2010/08/pengaruh-penilaian-prestasi-kerja.html Diakses pada tanggal 11 Oktober 2017 pukul 00.37 wib.

Yuli, Sri B. C. Manajemen Sumber Daya Manusia. Cetakan Pertama. UMM Press. Malang: 2005.

Zubaidah \& Ira Yuliana. Pengaruh Penilaian Prestasi Kerja Dan Kedisiplinan Terhadap Promosi Jabatan PT. Batamec Shipyard. Vol.7 No.1. Jurnal Akuntansi dan Bisnis (Akmenbis) Akademi Akuntansi Permata Harapan. Jakarta: 2017. 